\title{
In Vivo Imaging of Biodegradable Implants and Related Tissue Biomarkers
}

\author{
Leon Riehakainen ${ }^{1,2, * \mathbb{D}}$, Chiara Cavallini ${ }^{1}$, Paolo Armanetti ${ }^{1} \mathbb{D}$, Daniele Panetta ${ }^{1} \mathbb{D}$, Davide Caramella ${ }^{3}$ \\ and Luca Menichetti ${ }^{1}$ (D)
}

1 Institute of Clinical Physiology, National Research Council (IFC-CNR), 56124 Pisa, Italy; chiara.cavallini@ifc.cnr.it (C.C.); paolo.armanetti@ifc.cnr.it (P.A.); daniele.panetta@ifc.cnr.it (D.P.); luca.menichetti@ifc.cnr.it (L.M.)

2 College of Medicine, Sant'Anna School of Advanced Studies, 56127 Pisa, Italy

3 Specialization School in Radiodiagnostics, University of Pisa, 56100 Pisa, Italy; davide.caramella@unipi.it

* Correspondence: leon.riehakainen@ifc.cnr.it

Citation: Riehakainen, L.; Cavallini, C.; Armanetti, P.; Panetta, D.; Caramella, D.; Menichetti, L. In Vivo Imaging of Biodegradable Implants and Related Tissue Biomarkers. Polymers 2021, 13, 2348. https:// doi.org/10.3390/polym13142348

\section{Academic Editors:}

Francesco Boschetto, Elia Marin and Alfredo Rondinella

Received: 30 June 2021

Accepted: 12 July 2021

Published: 17 July 2021

Publisher's Note: MDPI stays neutral with regard to jurisdictional claims in published maps and institutional affiliations.

Copyright: (c) 2021 by the authors. Licensee MDPI, Basel, Switzerland. This article is an open access article distributed under the terms and conditions of the Creative Commons Attribution (CC BY) license (https:// creativecommons.org/licenses/by/ $4.0 /)$.

\begin{abstract}
Non-invasive longitudinal imaging of osseointegration of bone implants is essential to ensure a comprehensive, physical and biochemical understanding of the processes related to a successful implant integration and its long-term clinical outcome. This study critically reviews the present imaging techniques that may play a role to assess the initial stability, bone quality and quantity, associated tissue remodelling dependent on implanted material, implantation site (surrounding tissues and placement depth), and biomarkers that may be targeted. An updated list of biodegradable implant materials that have been reported in the literature, from metal, polymer and ceramic categories, is provided with reference to the use of specific imaging modalities (computed tomography, positron emission tomography, ultrasound, photoacoustic and magnetic resonance imaging) suitable for longitudinal and non-invasive imaging in humans. The advantages and disadvantages of the single imaging modality are discussed with a special focus on preclinical imaging for biodegradable implant research. Indeed, the investigation of a new implant commonly requires histological examination, which is invasive and does not allow longitudinal studies, thus requiring a large number of animals for preclinical testing. For this reason, an update of the multimodal and multi-parametric imaging capabilities will be here presented with a specific focus on modern biomaterial research.
\end{abstract}

Keywords: biodegradable implants; implant imaging; multimodal imaging; biomarkers; computed tomography (CT); positron emission tomography (PET); ultrasound (US); photoacoustic imaging (PAI); magnetic resonance imaging (MRI)

\section{Introduction}

Because of the invasive nature of implantation practice and associated organism reactions to the presence of foreign materials, imaging has been used as a tool to monitor the patient's condition ever since the discovery of X-rays in 1895. With the development of technologies and the increase in variety, the possible aspects and options for imaging have increased, allowing the visualization not only of structural condition, but also biological reactions and interactions.

Currently, implants used in orthopaedics, dentistry, reconstructive and cosmetic surgery use a large variety of materials, including permanent implants made of polymers (polyurethane, polyethylene, polypropylene, polymethylmethacrylate etc.) [1], ceramics (aluminium oxide, zirconium oxide, carbon-silicon etc.) and metals (titanium, stainless steel, gold, cobalt-chromium etc.) [2] However, it is unavoidable that most, if not all of the used materials have side effects, requiring additional treatment or even removal surgeries [3]. In some cases, complications such as patient discomfort, osteopenia due to stress shielding and chronic inflammatory reaction could be reduced or avoided if the 
implants would disappear after their effect is no longer required. For this reason, the development and application of biodegradable implants has become an attractive topic in implantology. This requires high quality testing and trials to confirm the safety and quality of these implants. One of these requirements is to have adequate imaging capabilities to follow up tissue healing and implant degradation in vivo.

Because of the ongoing diversification and narrow specialization in the field of science, the available information has become increasingly diverse and complicatedly interlinked. Concerns have been raised about the insufficient mutual understanding of the needs and capabilities among the specialists in the related fields such as medicine, biotechnology and imaging. As a result, the inadequate combinations of imaging modalities and targets have resulted in studies not being performed to their full potential. This review provides a detailed overview of the non-invasive imaging techniques commonly used in preclinical studies: computed tomography (CT), positron emission tomography (PET), ultrasound (US), PAI (photoacoustic imaging) and MRI (magnetic resonance imaging). The advantages and limitations of these modalities are evaluated for imaging the available biodegradable metallic, ceramic and polymer implants and the related tissue healing processes through targeting biomarkers of bone regeneration, angiogenesis and inflammation.

\subsection{Background}

With the scientific progress and development of new materials, by the 20th century, a variety of new substances and multi-phase materials were found and developed, such as alloys based on titanium, zirconium oxide, cobalt-chromium, nickel-chromium, stainless steels, polymers etc. [2] This had allowed the dental and bone implants to become a standard approach in defect repair and replacement.

With the improvement of the average quality of life and subsequent increase in requirements, attention was turned towards specially designed biodegradable implants that would allow faster healing, fewer side effects and better comfort. Despite the first biodegradable materials such as proteins (silk and collagen used in sutures) and metals (magnesium wires and plates) knowingly used for over a century, only recently has the scientific methodology been developed enough to allow a sufficiently reliable and comprehensive analysis of their effects on the living body.

Natural and synthetic polymers (proteins and poly[hydroxyl acids]), ceramics (bioactive glass, tricalcium phosphate, hydroxyapatite), metals ( $\mathrm{Mg}, \mathrm{Fe}, \mathrm{Zn}$ ) and their composites are known to be biodegradable [4] and already see a limited use in implantology (Figure 1). Their ability to perform their desired function without causing any local or systemic adverse response in the recipient is known as biocompatibility [5]. For an implant to perform its desired function, successful integration with the surrounding tissue is required. That, in turn, is a complex process involving aspects of wound healing, cell signalling, proliferation, adhesion, and growth, which need to be coordinated between multiple tissue types. In biodegradable implants, the process of corrosion is one of the main measures of biocompatibility, different from the traditional implants, where the corrosion is seen as a flaw. With these implants, in addition to the by-products of the degradation being produced, the surrounding tissues are continuously growing while the volume of the implants is correspondingly reduced. The balanced rate of degradation and growth are essential to ensure the correct maintenance of the mechanical integrity, especially in load-bearing structures such as bones [4] (Figure 2).

Based on the above, the potential targets for clinical and research imaging of biodegradable implants are: (i) immediate and long-term tissue and cell responses; (ii) tissue regeneration; (iii) implant integration (implant-tissue interface); and (iv) changes in implant structure. The biological processes have specific characteristics that are known as biomarkers [6] which can be used to evaluate the changes and to serve as targets for biomedical imaging. It is necessary to follow the degradation of the implants in vivo from mechanical, chemical and biological standpoints to ensure that they remain safe and functional through the whole duration of the treatment. 


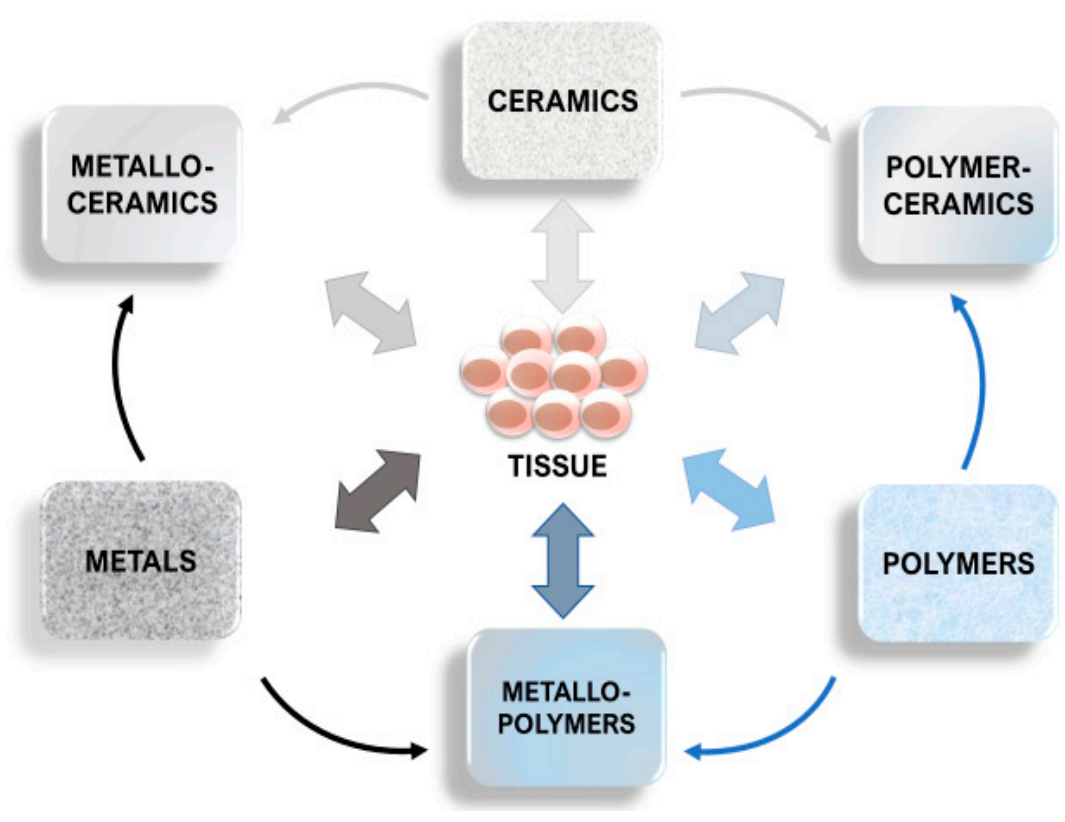

Figure 1. Implant types by materials. While most research focuses on tissue interaction with a single type of material, currently, the variety of available compound materials allows us to modify the material properties and their behaviour according to requirements.

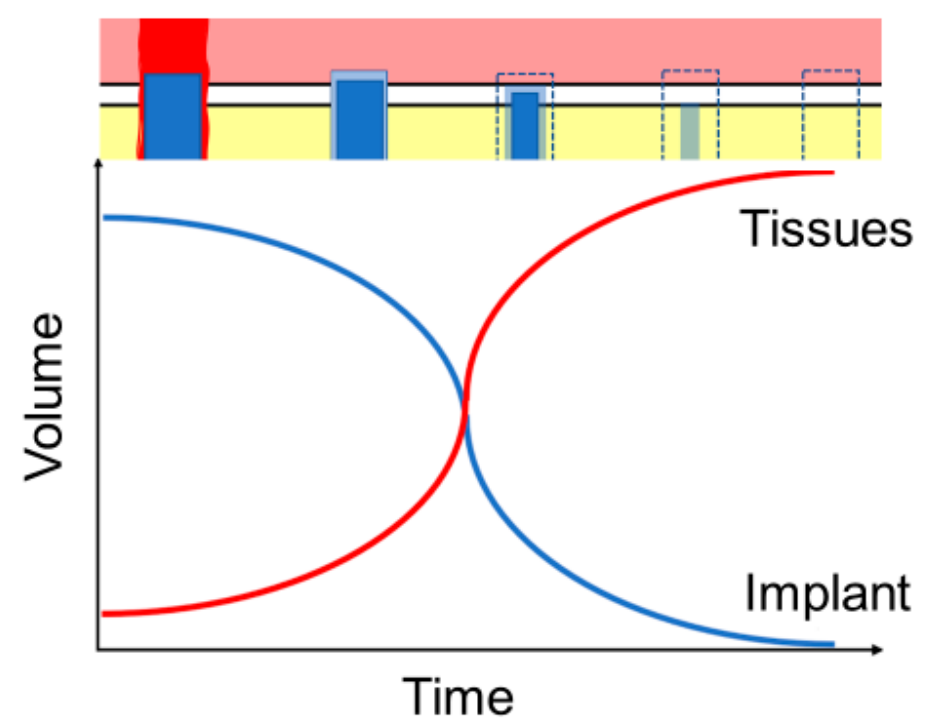

Figure 2. Ideal implant degradation and tissue regrowth dynamics against time. The rate of implant degradation has to be balanced to correspond to tissue regeneration, so the lost implant volume and mechanical strength are compensated by new tissue until the implant is completely degraded and absorbed.

\subsection{Tissue Response}

The damage to the living tissue and subsequent healing are closely associated with the inflammation process that is controlled by the immune system. While the actual details of cellular and biochemical reactions can differ depending on the severity and the site of the trauma, in general the inflammatory response can be separated into: (1) recognition of the harm by cell receptors (danger-associated molecular patterns of pattern recognition receptors); (2) activation of inflammatory pathways (such as intracellular signalling pathways that involve messenger molecules such as cytokines and receptors); (3) release of inflammation markers (mostly cytokines, proteins and enzymes involved in inflammatory cell activity); and (4) recruitment of inflammatory cells (macrophages, monocytes, neutrophils, 
lymphocytes, mast cells and platelets) [7]. In the presence of biodegradable implants, these responses are affected by the chemical and mechanical interaction between the tissues and the implants and released degradation products.

Blood vessel formation, or angiogenesis, is a crucial part of trauma healing, ensuring the necessary transport of the metabolic molecules and the formation of the regenerated tissues. This directly influences the biochemical processes associated with damage and subsequent healing. When dealing with the biodegradable implants, blood vessels are also involved in the disposal of the degradation products, such as in the case of metal ions [8].

Bone regeneration in the context of implants refers to the absorption of damaged tissue and the growth of new tissue around the bone implant. The involved pathways of chondrocyte, osteoclast and osteoblast activity regulation are highly complex, involving specific and non-specific tissue healing cell signals which are directly linked to hematoma from damaged blood vessels and inflammatory reactions [9]. Physically, the bone regeneration can be regarded as the growth of the bone volume to compensate for the loss caused by the damage and the gradual substitution of the degrading implant. Figure 3 shows the sequence of the bone healing stages, adapted from Einhorn et al. (2015) The efficiency of bone healing, especially at the remodelling phase, affects the changes in bone morphology and the osseointegration quality of the implant. That is especially important for the degrading implants, whose volume changes over time, because it directly affects the long-term implant stability and the quality of life of the patients.

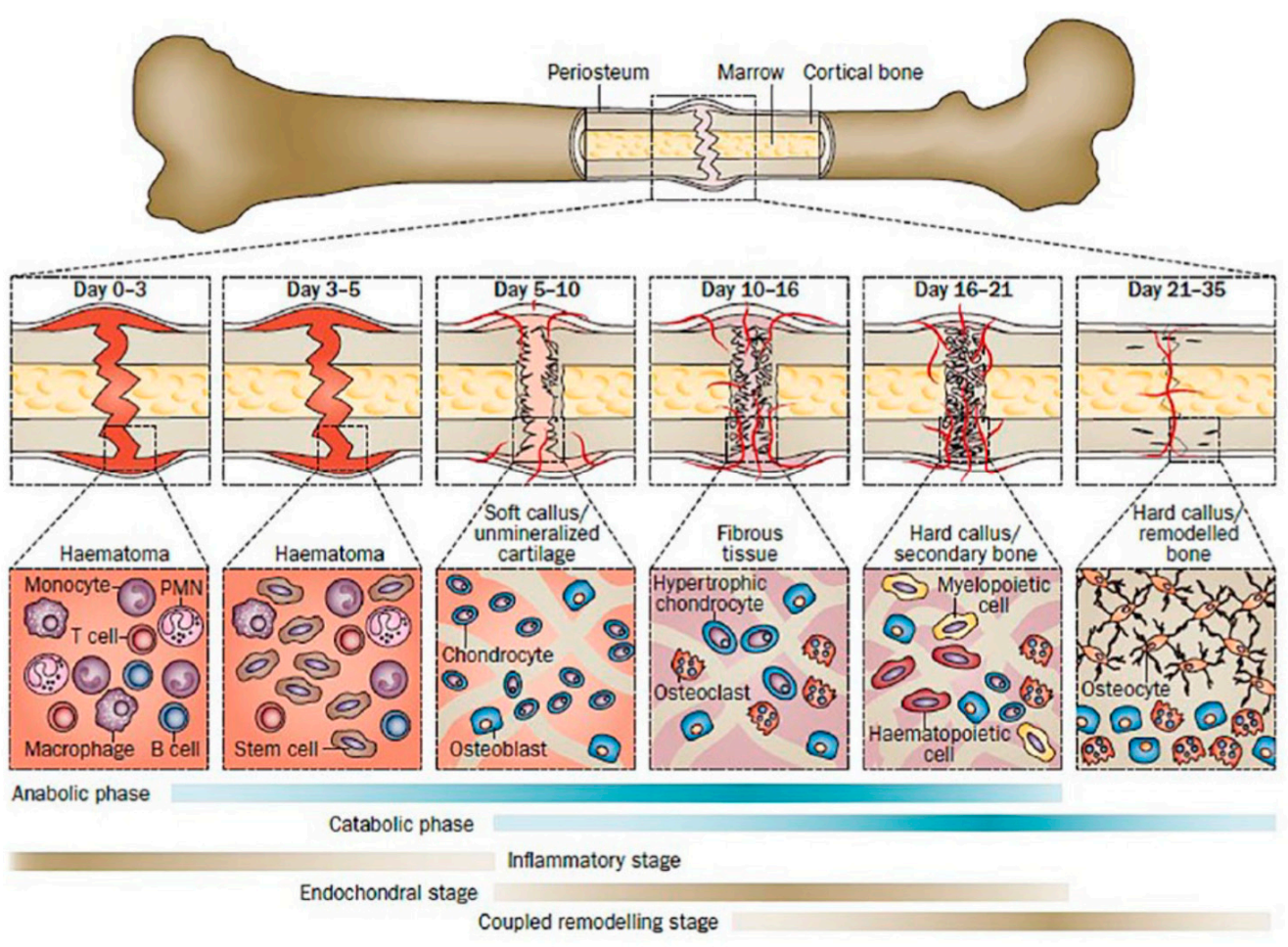

Figure 3. Healing stages of mouse closed femur fracture fixed with an intramedullary rod. Adapted with permission from Einhorn et al. (2015) [10] Copyright Springer Nature, 2014.

\subsection{Effects of Implant Structure}

Because they are essentially designed to become a part of the human body, both chemical and mechanical properties of the biodegradable implants have to fulfil strict requirements. They need to be biochemically neutral, non-toxic and must not trigger adverse reactions. At the same time, they must have a controlled, gradual rate of degradation while maintaining structural integrity, which is needed to allow the tissues to regenerate and compensate for the lost implant volume without the danger of damage from fragmentation. 
Chemical properties of implants are mostly influenced by the material they are made of. A major factor is the chemical reaction of the implanted material with the surrounding tissues, and corresponding changes in local biochemistry. The resulting changes in cell activity that affect the whole process of wound healing and tissue remodelling can be material-specific. By making use of alloys or otherwise mixed materials, the possible variables affecting degradation and interaction with the tissues can be manipulated with high flexibility and precision. Notable examples for this approach is the use of calcium, zinc, aluminium and various rare metals to adjust the degradation properties of magnesium implants [4,11] and hydroxyapatite composites that include collagen, poly(l-lactide) (PLLA), polydiolcitrates, polyvinyl alcohol or other polymers [12-14]. Figure 4 presents an example of clinical application of a specially designed compression screw from MgYREZr alloy (magnesium with yttrium, rare earth metal, and zirconium) and surface treatment to possess an oxide film and to combine both material and production methods to optimize their performance [15].

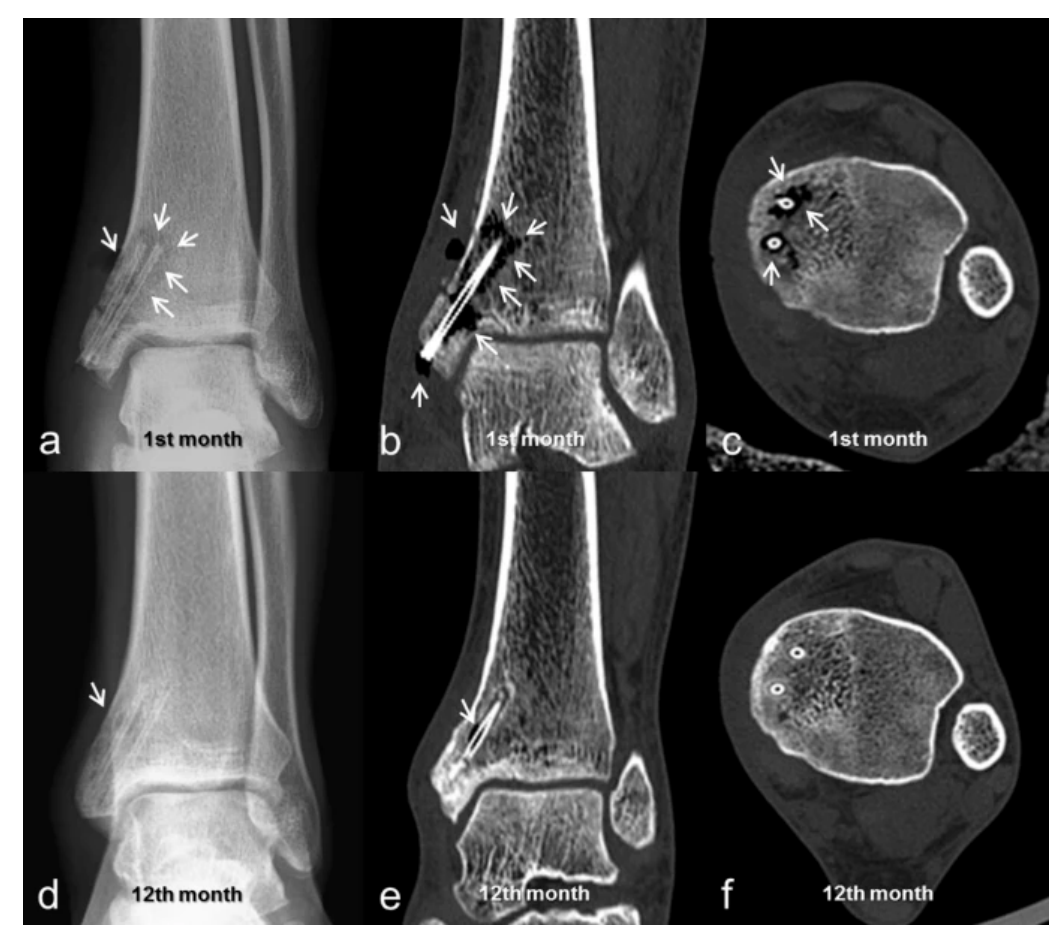

Figure 4. Isolated medial malleolar fracture treated with biodegradable magnesium screws (MAGNEZIX ${ }^{\circledR}$ CS; Syntellix AG, Hanover, Germany). (a-c) taken 1 month after implantation; $(\mathbf{d}-\mathbf{f})$ on 12 th month after implantation. (a,d) are radiographs; (b,c,e,f) are taken using CT. White arrows point at gas formation around implant. Reproduced from May et al. (2020) [15]. Copyright Springer Nature, 2020.

Mechanically, implants differ according to production methods, geometry and surface treatment. Production methods decide the microstructure-arrangements of the atoms, density, purity, distribution of additives etc. Depending on the material, these variables can have significant effects on the physical properties of the final product, such as absorption, scattering and attenuation of photons. Geometry, or the shape, of the implants is diverseboth due to specialized uses and also patent analogues from competing manufacturers. In the case of biodegradable implants, geometry also changes during the degradation process.

For imaging applications, it is necessary to consider the possible effects of the presence of irregular and thin shapes that can be difficult to recognize. Surface treatment, as the border between the bulk of the implant and the body, has the principal role of interaction with the tissues. Since this decides the success of implant integration, it is the primary focus of imaging, be it in the clinical or research approach. The use of coatings to promote 
the integration, reduce the adverse reactions and regulate the degradation is increasing, with notable examples being magnesium implants coated with hydroxyapatite, polymers, oxide layers etc $[16,17]$. A variety of biodegradable materials from all three types (ceramics, polymers, metals) that have been reported in the literature are listed in Table 1.

Table 1. Biodegradable implant materials reported in the literature, the main constituent atoms and average density [18-32].

\begin{tabular}{|c|c|c|c|}
\hline & & Main Atoms & Density \\
\hline \multicolumn{4}{|l|}{ Ceramics } \\
\hline \multicolumn{4}{|l|}{ Calcium phosphates } \\
\hline Hydroxyapatite & & $\mathrm{Ca}, \mathrm{P}$ & $3.1-3.2$ \\
\hline \multirow[t]{2}{*}{ Dicalcium phosphate dihydrate } & DCPD & $\mathrm{Ca}, \mathrm{P}$ & 2.3 \\
\hline & Brushite & $\mathrm{Ca}, \mathrm{P}$ & $2.3-2.33$ \\
\hline Tricalcium phosphate & TCP & $\mathrm{Ca}, \mathrm{P}$ & 3 \\
\hline Tetracalcium phosphate & $\mathrm{TeCP}$ & $\mathrm{Ca}, \mathrm{P}$ & 3.06 \\
\hline Bioglass & & $\mathrm{Si}, \mathrm{Ca}, \mathrm{Na}, \mathrm{O}$ & $2.6-2.7$ \\
\hline \multicolumn{4}{|l|}{ Polymers } \\
\hline Poly(amino acids) & e.g., poly( $\gamma$-benzyl-L-glutamate) & $\mathrm{C}, \mathrm{H}$ & 1.2 \\
\hline Poly(ortho esters) & & $\mathrm{C}, \mathrm{O}, \mathrm{H}$ & $0.39-0.46$ \\
\hline Polyphosphazenes & & $\mathrm{P}, \mathrm{N}$ & \\
\hline Poly(propylene fumarate) & & $\mathrm{C}, \mathrm{O}$ & 0.998 \\
\hline \multicolumn{4}{|l|}{ Polyesters } \\
\hline \multirow[t]{3}{*}{ Aliphatic } & Polylactide & $\mathrm{C}, \mathrm{H}, \mathrm{O}$ & $1.25-1.27$ \\
\hline & Polyglycolide & $\mathrm{C}, \mathrm{H}, \mathrm{O}$ & $1.5-1.6$ \\
\hline & Copolymers & & \\
\hline \multirow[t]{4}{*}{$\begin{array}{l}\text { Polyhydroxy- } \\
\text { alkanoates }\end{array}$} & $\begin{array}{l}\text { Polyhydroxy- } \\
\text { butyrate }\end{array}$ & $\mathrm{C}, \mathrm{H}, \mathrm{O}$ & $1.18-1.26$ \\
\hline & $\begin{array}{l}\text { Polyhydroxy- } \\
\text { valerate }\end{array}$ & $\mathrm{C}, \mathrm{H}, \mathrm{O}$ & \\
\hline & $\begin{array}{l}\text { Polyhydroxy- } \\
\text { hexanoate }\end{array}$ & $\mathrm{C}, \mathrm{H}, \mathrm{O}$ & \\
\hline & $\begin{array}{l}\text { Polyhydroxy- } \\
\text { octanoate } \\
\text { Copolvmers }\end{array}$ & $\mathrm{C}, \mathrm{H}, \mathrm{O}$ & \\
\hline Polycaprolactone & & $\mathrm{C}, \mathrm{H}, \mathrm{O}$ & $1.10-1.15$ \\
\hline Polydioxanone & & $\mathrm{C}, \mathrm{O}$ & 1.318 \\
\hline \multicolumn{4}{|l|}{ Metals } \\
\hline Magnesium & Alloyed with $\mathrm{Ca}, \mathrm{Zn}, \mathrm{Al}$, rare metals & $\mathrm{Mg}$ & 1.738 \\
\hline Iron & & $\mathrm{Fe}$ & 7.874 \\
\hline Zinc & & $\mathrm{Zn}$ & 7.140 \\
\hline \multicolumn{4}{|l|}{ Body tissues } \\
\hline Bone (cortical) & & & 1.9 \\
\hline Muscle (skeletal) & & & 1.06 \\
\hline
\end{tabular}

\section{Features of the Imaging Techniques}

\subsection{Computed Tomography}

Computed tomography, being the three-dimensional version of the conventional planar X-ray scan, relies on the same principles of using electromagnetic radiation (photons) and the difference in its attenuation rate by different matter. As photons interact with the surrounding matter, they can be absorbed by a photoelectric effect, or undergo scattering through incoherent (Compton) or coherent (Rayleigh) scattering.

In the photoelectric effect, the incident photon is absorbed by the atom while displacing the electron from its shell, which creates the contrast in the rays absorbed by the matter, creating the image. This effect is dependent on electron binding energies, as the lower binding energy allows lower energy photons to interact, and the probability is generally proportional according to formula $Z^{3} / E^{3}(Z=$ atomic number; $E=$ photon energy). Except for the absorption edge points in the absorption spectrum of the substance, where there is a sharp rise in absorption coefficient as the energy increases, and the energy of the photon becomes equal to the energy of the electron shell. The combination of the scattering and ab- 
sorption coefficients is represented as mass absorption coefficient (in $\mathrm{cm}^{2} / \mathrm{g}$ ). In radiology, the mass absorption coefficient has little practical use, instead these values are multiplied by density to obtain linear absorption coefficient $\left(\right.$ in $\mathrm{cm}^{-1}$ ). Table 2 provides selected values of linear absorption coefficients based on densities from Table 1 for biodegradable implant bulk materials and references (titanium, skeletal muscle and cortical bone) across the range of clinical CT photon energies. Depending on microstructure and alloy composition, the density and therefore the resulting linear absorption coefficient values can significantly differ. For this, Table A1 in Appendix A provides raw calculated total attenuation coefficients without coherent scattering for most materials and the energy range. Beam hardening is the most common implant-related artefact, created when lower energies of the polychromatic X-ray beam are absorbed while letting the high energy photons to pass through, thus distorting the calculation of thickness-based attenuation data [33]. That can be reduced by achieving a monochromatic beam (usually simulated by dual energy CT) or by increasing photon energies (increased radiation dose). While the clinical CT photon energies are between 5 (mammography) and 150 (abdominal) keV [34], the actual usable energies are further limited by the volume (and density) of the imaging target and technical limitations of the available equipment.

Table 2. Calculated linear attenuation coefficients $\left(\mathrm{cm}^{-1}\right)$ for biodegradable implant materials (magnesium and hydroxyapatite), titanium, cortical bone and skeletal muscle from to 5 to $150 \mathrm{keV}$. Values can vary depending on structure and density.

\begin{tabular}{cccccc}
\hline $\begin{array}{c}\text { Photon Energy } \\
\text { (keV) }\end{array}$ & Mg & Ti & Hydroxyapatite & $\begin{array}{c}\text { Cortical } \\
\text { Bone }\end{array}$ & $\begin{array}{c}\text { Skeletal } \\
\text { Muscle }\end{array}$ \\
\hline 5 & 273.21 & 3073.09 & 967.20 & 350.59 & 44.08 \\
6 & 161.41 & 1941.18 & 593.03 & 213.70 & 25.47 \\
7.112 & & & & & 15.23 \\
7.112 & & & & & 15.25 \\
8 & 69.36 & 906.61 & 270.07 & 96.65 & 10.67 \\
9.659 & & & & 56.85 & 6.03 \\
9.659 & & & & 56.89 & 6.04 \\
10 & 35.70 & 494.76 & 144.49 & 51.53 & 5.44 \\
15 & 10.55 & 159.02 & 45.20 & 16.10 & 1.65 \\
20 & 4.48 & 69.62 & 19.59 & 7.03 & 0.78 \\
30 & 1.44 & 21.42 & 6.11 & 2.29 & 0.35 \\
40 & 0.74 & 9.35 & 2.81 & 1.13 & 0.25 \\
50 & 0.50 & 5.04 & 1.65 & 0.72 & 0.22 \\
60 & 0.39 & 3.14 & 1.13 & 0.54 & 0.20 \\
80 & 0.31 & 1.63 & 0.73 & 0.39 & 0.18 \\
100 & 0.27 & 1.10 & 0.58 & 0.34 & 0.17 \\
120 & 0.25 & 0.86 & 0.50 & 0.31 & 0.16 \\
140 & 0.24 & 0.73 & 0.46 & 0.28 & 0.16 \\
150 & 0.23 & 0.68 & 0.44 & 0.28 & 0.15 \\
\hline
\end{tabular}

Therefore, to achieve a clear image of an implant, there needs to be sufficient contrast between it and the surrounding tissues while staying within the acceptable photon energy range and ensuring that the attenuated photons do not go below the detector minimum detection range. The polymers, bioengineered implants and grafts are often indistinguishable from the surrounding tissues because of the similar absorption properties. To image these, using CT requires special approach to enhance the contrast, such as alloying the implant material to create composites with desirable properties or using surface coating. The widely spread titanium, stainless steel and zirconium oxide implants have absorbance coefficients significantly higher than those of the body tissues, so they are easily distinguishable. However, the presence of metals produces significant artefacts that reduces the quality of the obtained images [35-37]. At the same time, the developing magnesium-based biodegradable implants are less affected by this effect [38]. 
Despite the limitations, CT is a reliable and trusted method for imaging bone pathologies, structural changes and with the use of contrast agents, vascularisation. According to data in Table 2 (graphically represented in Figure 5), only a few implants have a linear attenuation similar to cortical bone (such as magnesium and ceramics), and even then, most materials can provide sufficient border contrast. That, and artefact reduction, is achieved by using dual energy protocols $[39,40]$. At the same time, CT is often necessary for surgery planning and is helpful in detecting implant-related complications including inflammations [41] and osteolysis [42].
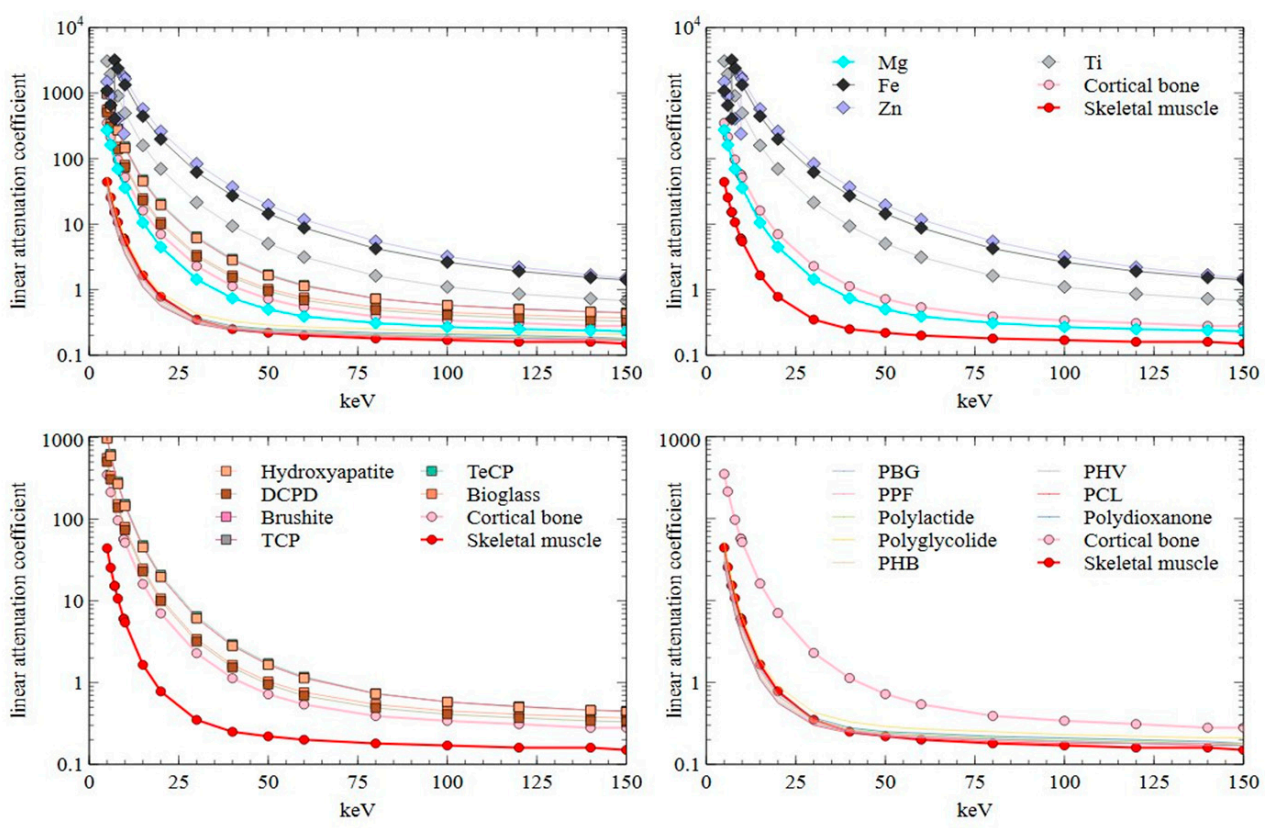

Figure 5. Plotted linear attenuation coefficient data of biodegradable implant materials and cortical bone and skeletal muscle. $\quad$ PBG $=$ poly $(\gamma$-benzyl-L-glutamate $) ; \mathrm{PPF}=$ polypropylene fumarate; $\mathrm{PHB}=$ polyhydroxybutyrate; $\mathrm{PHV}=$ polyhydroxyvalerate; $\mathrm{PCL}=$ polycaprolactone.

\subsection{Positron Emission Tomography}

Positron emission tomography uses positrons that are emitted during beta plus $\left(\beta^{+}\right)$ decay of radionuclides that are the signalling components of the radiotracers. The emitted positron interacts with a surrounding electron and the mutual annihilation reaction produces two photons of gamma energy spectrum $(511 \mathrm{keV})$ that move in opposite directions at a $180^{\circ}$ angle from each other. The photons are detected, and the annihilation event location is reconstructed using corresponding algorithms.

While a metabolically inactive implant would have little to no interaction with the radiotracer, PET allows us to specifically image the metabolic activity of chosen pathways, which is indispensable for the evaluation of the tissues affected by the implantation. For this reason, the targets of the imaging are metabolites and pathways that are relevant for the study focus. In the case of biodegradable implants, this involves their interaction with the surrounding tissues during the inflammatory stage and the following processes of tissue regeneration, implant integration, degradation and replacement. Osseointegration of bone implants and the substitution of degraded material with new bone can be monitored through the increase of calcium, for example through the use of ${ }^{18} \mathrm{~F}$ that binds to hydroxyapatite, thus creating fluorapatite [43]. Inflammation associated with trauma healing and the presence of foreign material in the body is routinely imaged by quantifying the increase in glucose metabolism by using fluorodeoxyglucose (FDG) [44]. Wound healing and regeneration of the surrounding tissues can be associated with the growth of blood vessels and the activity of associated integrins such as $\alpha_{V} \beta_{3}$ [45,46] and $\alpha_{V} \beta_{5}$ [47], which are targeted by tracers based on RGD-peptides (e.g., ${ }^{68} \mathrm{Ga}-\mathrm{NODAGA}-\mathrm{RGD}$ [47]). There 
are also groups of biomarkers, such as matrix metalloproteinases (MMPs, a family of endopeptidases), that have a varied role in biochemical activity, for example MMP-9 has been shown to be associated with early extracellular matrix (ECM) re-organization [48], and MMP-12 is linked to macrophage activity and vascular pathologies [49]. In Figure 6, from a study of asymptomatic patients with hip and knee join replacement [50], an ${ }^{18} \mathrm{~F}-\mathrm{NaF}$ tracer was used to set a baseline to evaluate implant stability based on the osteoblast and osteoclast activity and related presence of bone minerals.

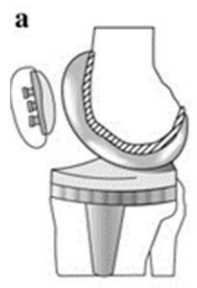

c

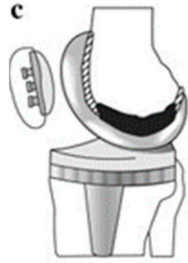

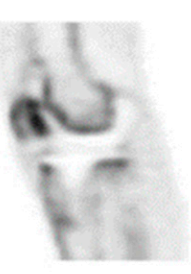

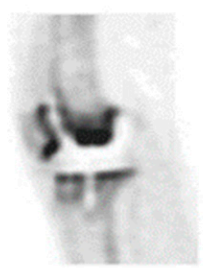

e

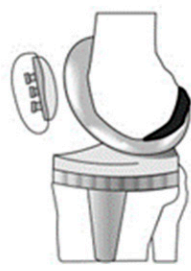

b

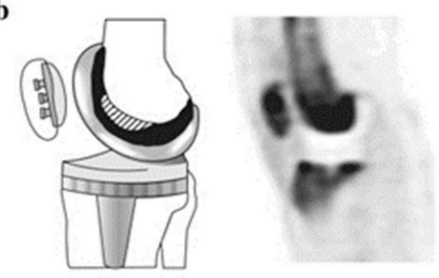

d

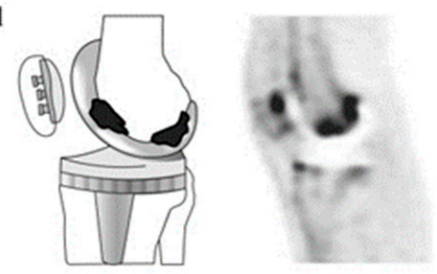

Figure 6. Diagrams and representative PET images showing the five types of ${ }^{18} \mathrm{~F}-\mathrm{NaF}$ uptake pattern in the femoral component of knee prostheses. Black areas represent areas of severely increased uptake and shaded areas represent slightly increased uptake of radiotracer. Adapted with permission from Son et al. (2016) [50] Copyright Springer Nature, 2016.

However, even if the radiotracer does not interact with the implant, the gamma photons that are the basis of the detection are influenced by the presence of foreign matter, resulting in additional absorption, attenuation, deflection and scatter. To illustrate this, Table 3 lists the linear attenuation values for biodegradable implant materials at the energy level of emitted gamma photons. Because general image reconstruction algorithms are designed to work on the basis of natural body tissues, the implants cause the appearance of image artefacts, mostly due to the use of CT attenuation maps [51,52]. To deal with this, similar to CT and MRI protocols, implants are recommended to be oriented along the $x$-axis of the scan and to have a uniform shape without sharp angles.

Table 3. Biodegradable implant materials and their linear attenuation coefficients $\left(\mathrm{cm}^{-1}\right)$ of $511 \mathrm{keV}$ photons.

\begin{tabular}{ccc}
\hline Type & Material & Attenuation Coefficient at $\mathbf{5 1 1} \mathbf{~ k e V}$ \\
\hline \multirow{4}{*}{ Metals } & $\mathrm{Mg}$ & 0.15 \\
& $\mathrm{Fe}$ & 0.64 \\
& $\mathrm{Zn}$ & 0.58 \\
& $\mathrm{Ti}$ & 0.36 \\
\hline \multirow{4}{*}{ Ceramics } & Hydroxy- apatite & 0.27 \\
& DCPD & 0.20 \\
& Brushite & 0.21 \\
& TCP & 0.27 \\
& TeCP & 0.27 \\
& Bioglass & 0.23 \\
\hline
\end{tabular}


Table 3. Cont.

\begin{tabular}{ccc}
\hline Type & Material & Attenuation Coefficient at 511 keV \\
\hline & poly( $\gamma$-benzyl-L-glutamate $)$ & 0.11 \\
Polypropylene fumarate & 0.11 \\
Polymers & Polylactide & 0.11 \\
& Poly-glycolide & 0.14 \\
& Polyhydroxy-butyrate & 0.11 \\
& Polyhydroxy-valerate & 0.11 \\
& Polycapro- lactone & 0.11 \\
& Poly-dioxanone & 0.12 \\
\hline \multirow{2}{*}{ Tissues } & Cortical bone & 0.17 \\
& Skeletal muscle & 0.10 \\
\hline
\end{tabular}

\subsection{Ultrasound Imaging}

As one of the most safe, comfortable and simple imaging modalities, ultrasound is widely used to study structures and physical processes happening under the cover of the soft tissues. Ultrasound imaging uses the principle of sound waves echoing from the borders of mechanically different tissues [53], due to the variation of acoustic impedance. At the same time, the higher the sound frequency, the higher is the resolution but lower the penetration depth. Increased energy increases the imaging depth, however that can lead to side effects such as heating, acoustic cavitation and acoustic streaming [54]. The heating is one of the primal concerns associated with implant imaging, as the healing process can be by thermal damage [55].

Acoustic impedance is defined as material density (Table 1) and sound velocity in that material. The larger the difference between two tissues, the higher is the number of sound waves that are reflected, and the clearer is the image border. Considering that a significant number of orthopaedic implants is inside the bone, there are at least two acoustic impedance borders in between-from muscle to bone and from bone to implant. As a result, only a very limited amount of echo signal from implant within the bone can reach the receiver. Taking into account the attenuation, scatter, reflection and all the noise, ultrasound is of limited use for imaging such implants. Furthermore, it is important that both density and sound velocity are heavily dependent on the structure and composition of the materials, which can significantly differ even in similar alloys, composites and polymers.

Although US is limited to soft tissues and the topography of hard surfaces [56], it still is a suitable tool for non-invasive and low-discomfort monitoring of the conditions outside the bone inner volume. That allows to evaluate the external aspect of bone and external implants such as fixation plates, monitor the wound healing and the inflammation process at the implantation site and the healing of bone fractures [57]. For biodegradable implants, US is suitable to observe the changes in surface structures caused by implant degradation and bone growth. It is also used to monitor soft tissue and bone healing and to evaluate the state of the inflammation at the wound site based on the measurements of accumulated liquid and oedema.

\subsection{Photoacoustic Imaging}

Photoacoustic imaging (PAI) relies on the optical absorbance qualities of the tissues and included optical contrast agents down to molecular level. The target chromophores absorb the specific wavelength laser pulses, and the optical energy is converted into detectable sound pressure waves. These chromophores can be endogenous (free and bound water, oxyhaemoglobin, deoxyhaemoglobin, melanin, lipids) and exogenous (mostly small molecule dyes - indocyanine green, Methylene Blue Dye, nanoparticles, designed reporter gene agents etc.) [58].

The use of PAI for implant monitoring has been previously explored in studies such as by Lee et al. [59] (Figure 7), who achieved reasonable ability to distinguish titanium implant covered by bone or meat, at depths relevant for dentistry applications. However, the depth 
penetration limit and noticeable optical attenuation makes it increasingly difficult to image the targets that are located deeper than 10-20 mm, limiting the clinical application of PAI to targets near the surface [60]. At the same time, PAI resolution is dependent on the depth based on "factor of 200 rule of thumb", with resolution being 1/200th of the depth [61,62]. For preclinical applications, where small animal studies are prevalent, PAI is less limited by depth, and can be used to gather molecular data from the whole target area [63].
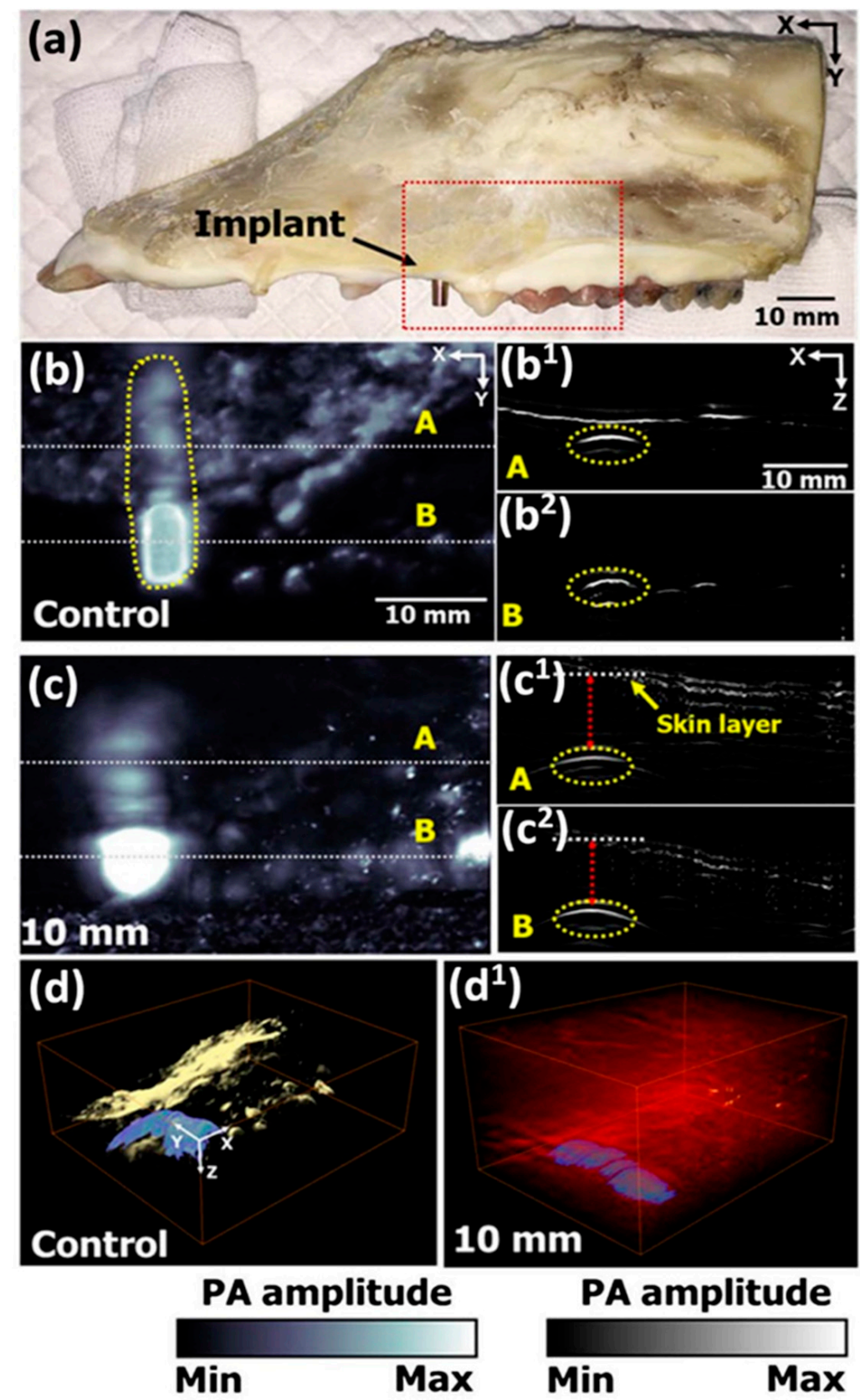

Figure 7. Ex vivo PA image of porcine jawbone with titanium implant abutment (EZ Post, MIEP3525HT, Megagen, Korea) and a fixture (MIIF3008C, Megagen, Korea). (a) Jawbone specimen. (b) PA image at $1064 \mathrm{~nm}$ excitation. (c) PA MAP images from (b) under $10 \mathrm{~mm}$ of chicken tissue. (d) 3D render of bare bone specimen (d) and under $10 \mathrm{~mm}$ chicken tissue $\left(\mathbf{d}^{\mathbf{1}}\right) .\left(\mathbf{b}^{\mathbf{1}}, \mathbf{b}^{\mathbf{2}}\right)$ and $\left(\mathbf{c}^{\mathbf{1}}, \mathbf{c}^{\mathbf{2}}\right)$ are cross-sectional PA images of the dashed line areas in corresponding $(\mathbf{b}, \mathbf{c})$ images.Reprinted with permission form Lee et al. (2017) [59] Copyright The Optical Society of America, 2017.

Photoacoustic imaging also has potential to be used with biodegradable implants. The possibility to observe in vivo the molecular activity during implant degradation is 
one of the desired tools in the relevant research. Notably, photoacoustic measurements of oxyhaemoglobin and deoxyhaemoglobin levels reflect the state of blood supply and angiogenesis in the wound area.

\subsection{Magnetic Resonance Imaging}

MRI is one of the most advanced, non-invasive and low-discomfort imaging modalities, which is only limited by high costs, personnel qualification level and incompatibility with ferromagnetic materials. MRI is based on nuclear magnetic polarization created through static magnetic field $\left(B_{0}\right)$, which is disturbed with a pulse of radiofrequency $(\mathrm{RF})$ field at Larmor frequency $\left(\mathrm{f}_{\mathrm{o}}\right)$, which in turn is calculated based on the strength of magnetic field and gyromagnetic ratio $(\gamma)$ of the targeted nucleus or particle (with formula being $\mathrm{f}_{\mathrm{o}}=\gamma \times B_{0}$ ) [53]. The resulting disturbance in equilibrium is measured as alternating voltage in surrounding detection coils. The speed at which the disturbed magnetic polarization goes through the process of normalization can be used to differentiate the condition of the tissues and reconstruct this as a visual image.

MRI is best at imaging soft tissues and liquids, because of the high content of $\mathrm{H}^{+}$ protons [64]. This makes it suitable for imaging inflammation through gadolinium contrast [65] or by detecting liquid accumulations such as oedema and synovitis. Similarly, MRI is actively used to study vascularization through blood flow quantification analysis using perfusion MRI techniques such as arterial spin labelling (ASL), dynamic susceptibility contrast (DSC), dynamic contrast enhanced (DCE), and intravoxel incoherent monition (IVIM) tools [66].

Due to the operating principle of MRI, hard objects without free $\mathrm{H}^{+}$protons, like bones and implants, are not optimal imaging targets. However, with bone still being living tissue, it remains possible to image osteolysis at the damage sites [67], giving a clear view of the borders. It is also possible to detect non-ferromagnetic implants such as poly(lactic-co-glycolic acid) (PLGA), tricalcium phosphate (TCP) and polylactic acid (PLA) based on their negative contrast $[68,69]$ and that should carry over to other biodegradable ceramic and polymer implants. Some materials such as glass and plastics are known to be diamagnetic - magnetized in the direction opposite to the magnetic field. However, there is no data available about diamagnetic biodegradable implant materials such as bioglass and polymers [70]. While magnesium and zinc are also non-ferromagnetic, their difference in magnetic susceptibility from surrounding tissues still produces a low level of imaging artefacts and geometric distortions [38,71]. Iron, as a strongly magnetic material, makes implants unsuitable for MRI imaging.

\section{Discussion and Conclusions}

Due to the ever-expanding list of imaging targets and the constant refinement of imaging technologies, it is becoming increasingly complex to choose a single appropriate modality. Depending on variables such as implant material, surrounding tissue and placement depth, the same target may require different imaging techniques or a combination of them. Thanks to the advances in composite material development, it is possible to produce implants that have drastically different properties.

On one hand, it improves the biocompatibility of composites, on the other hand, these composites are often patented. This results in competing manufacturers producing their own alternatives and patenting these in turn. Hence, there are many new materials, often with severely lacking information about their composition and even some basic physical properties. This further complicates imaging studies, since without knowing these properties, it is more difficult and time-consuming to design and perform the studies. For the same reasons, the information about some modalities may be underrepresented compared to others. For example, because X-ray and CT have been established as the gold standard in multiple areas of material and biomedical studies, it was possible to provide material attenuation data relevant for the modality. At the same time, information about magnetic susceptibility, sound velocity and absorption spectrum (for MRI, US and PAI) for 
biodegradable materials was insufficient for an adequate compilation. It is necessary for implant material studies to put more focus on reporting these characteristics.

To improve the quality of the data obtained using imaging, one of the approaches is to design implants that consider the specifics of the imaging modality. With the developing technologies of custom production such as 3D printing, this is a possible future for preclinical studies that are aiming to understand the details of the body and implant interactions. As an example, it is possible to include chromophores to the bulk material, producing an implant whose degradation kinetics can be followed with PAI at the molecular level. However, such an approach is unsuitable for clinical use and for studying the already existing materials. This is where the multimodal imaging can be of advantage. By achieving an optimal combination of imaging techniques that help to cancel out or mitigate the individual shortcomings, the diagnosis, evaluation and treatment can be done with the highest accuracy and reliability.

When making use of multimodal imaging, the imaging techniques need to be chosen based on how suitable they are for the intended combination of the target(s) and the aim(s). As an example, angiogenesis is a common and reliable imaging biomarker for evaluating tissue healing, because new blood vessels are required to support the growth and functioning of the new tissues. It can be imaged using all imaging modalities mentioned in this paper (CT, PET, US, PAI and MRI). By way of example, using PET, the angiogenetic process (i.e. new blood vessel formation associated to vascular endothelium proliferation) can be studied non-invasively by assessing the regulation of the integrin expression (among the integrin superfamily the $\alpha_{V} \beta_{3}$ isoform is the most used). The $\alpha_{V} \beta_{3}$ expression is quantified using a tracer such as ${ }^{68}$ Ga-NODAGA-RGD [72,73] and is one of the few ways to produce images of in vivo metabolism. The drawback of using PET is limited resolution (1-2 mm), which, while rarely crucial in clinical studies, can be a limiting factor for small animal studies due to the scaling. However, PET is commonly combined with CT and also with MRI, which have well established angiography techniques, allowing us to image vasculature in high detail. At the same time, the different modalities allow us to better visualise the borders between the implant and the tissues, which is also usable for artefact correction. Alternatively, because PET has necessary intervals between imaging, using different tracers to image the same target is problematic. In such cases, PAI can be utilised to image $\alpha_{\mathrm{V}} \beta_{3}$ expression, and PET to follow bone mineralization with the help of ${ }^{18} \mathrm{~F}-\mathrm{NaF}$.

Table 4 combines the previously mentioned imaging modalities and their suitable imaging targets that have been reported in the literature and can be applied for implant studies.

Table 4. Preclinical imaging modalities, their properties and application in relation to biodegradable implants.

\begin{tabular}{|c|c|c|c|c|c|}
\hline & $\mathrm{CT}$ & PET & US & PAI & MRI \\
\hline Depth & - [72] & - [72] & $>50$ mm [74] & $>50$ mm [60] & - \\
\hline Spatial resolution & $0.05 \mathrm{~mm}$ [75] & 1-2 mm [72] & $\begin{array}{c}\text { Up to } 0.15 \mathrm{~mm} \text { at } 25 \\
\mathrm{MHz}[76]\end{array}$ & $\begin{array}{c}1 / 200 \text { th of depth } \\
{[60,61]}\end{array}$ & $>0.1 \mathrm{~mm}[77]$ \\
\hline \multicolumn{6}{|c|}{ Target } \\
\hline Bone tissue & \multirow{3}{*}{$\begin{array}{l}\text { Implants and tissues } \\
\text { of different } \\
\text { attenuation }\end{array}$} & $\begin{array}{l}\text { Molecular activity } \\
\text { with target tracers }\end{array}$ & Surface topography & Surface topography & Unsuitable \\
\hline Soft tissues & & $\begin{array}{l}\text { Molecular activity } \\
\text { with target tracers }\end{array}$ & $\begin{array}{l}\text { Structures and } \\
\text { borders }\end{array}$ & $\begin{array}{l}\text { Structures and } \\
\text { molecular } \\
\text { chromophores }\end{array}$ & Highly efficient \\
\hline Implant & & & Surface topography & $\begin{array}{c}\text { Mostly surface } \\
\text { topography }\end{array}$ & Unsuitable \\
\hline \multicolumn{6}{|c|}{ Biomarkers } \\
\hline Inflammation & $\begin{array}{l}\text { Visual oedema and } \\
\text { liquid accumulation, } \\
\text { liquid iodine } \\
\text { contrast [41] }\end{array}$ & e.g., ${ }^{18}$ F-FDG [78] & $\begin{array}{l}\text { Visual oedema and } \\
\text { liquid accumulation }\end{array}$ & $\begin{array}{l}\text { Oxygen level } \\
\text { dynamics [79] }\end{array}$ & $\begin{array}{l}\text { Visual oedema and } \\
\text { liquid accumulation }\end{array}$ \\
\hline
\end{tabular}


Table 4. Cont

\begin{tabular}{|c|c|c|c|c|c|}
\hline & CT & PET & US & PAI & MRI \\
\hline Bone healing & Visual changes & $\begin{array}{c}\text { e.g., }{ }^{18} \mathrm{~F}-\mathrm{NaF} \\
{[44,72.73]}\end{array}$ & $\begin{array}{l}\text { Exceptional for early } \\
\text { ossification [57] }\end{array}$ & $\begin{array}{l}\text { Chromophores; } \\
\text { tissue morphology } \\
\text { changes during } \\
\text { remodelling }\end{array}$ & $\begin{array}{c}\text { Contrast of low } \\
\text { signal from bone } \\
\text { with high signal from } \\
\text { soft tissues [80] }\end{array}$ \\
\hline Angiogenesis & $\begin{array}{l}\text { blood vessels with } \\
\text { iodine contrast [81] }\end{array}$ & $\begin{array}{c}\text { e.g., }{ }^{68} \text { Ga-NODAGA- } \\
\text { RGD [47]; } \\
{ }^{68} \text { Ga-NOTA-RGD } \\
{[47,82] ;{ }^{68} \text { Ga-DOTA- }} \\
\text { E[c(RGDfK) }]_{2} \text { [83] }\end{array}$ & $\begin{array}{c}\text { Vascular imaging } \\
\text { using microbubbles } \\
\text { and binding agents } \\
{[84,85]}\end{array}$ & $\begin{array}{c}\text { Integrin-binding } \\
\text { chromophores; blood } \\
\text { oxygenation }\end{array}$ & $\begin{array}{l}\text { e.g., Gadolinium } \\
\text { contrast, perfusion } \\
\text { capacity [86] }\end{array}$ \\
\hline Advantages & Simple, fast & $\begin{array}{l}\text { Large choice of } \\
\text { radiotracers for } \\
\text { different targets, } \\
\text { possible to design } \\
\text { tracers for } \\
\text { specific targets; } \\
\text { metabolic data }\end{array}$ & $\begin{array}{l}\text { Simple; non-invasive; } \\
\text { no contraindications }\end{array}$ & $\begin{array}{l}\text { Can image molecular } \\
\text { activity; differentiate } \\
\text { targets based on } \\
\text { absorption spectra }\end{array}$ & $\begin{array}{l}\text { High resolution and } \\
\text { depth; very good soft } \\
\text { tissue differentiation; } \\
\text { possible to use } \\
\text { contrast agents }\end{array}$ \\
\hline Disadvantages & $\begin{array}{l}\text { Radiation; requires } \\
\text { high attenuation } \\
\text { between target and } \\
\text { surroundings; } \\
\text { contrast agents } \\
\text { require injections; } \\
\text { implant artefacts } \\
{[35-37,40,78]}\end{array}$ & $\begin{array}{c}\text { Radiation; high price; } \\
\text { complexity; } \\
\text { injections; long } \\
\text { duration; requires } \\
\text { either in-house } \\
\text { isotope production } \\
\text { and tracer laboratory } \\
\text { or be within } \\
\text { transportation range }\end{array}$ & $\begin{array}{l}\text { Limited depth; can't } \\
\text { image inside } \\
\text { hard objects }\end{array}$ & $\begin{array}{l}\text { Very limited depth; } \\
\text { light absorption; } \\
\text { complexity; } \\
\text { exogenous contrast } \\
\text { agents require } \\
\text { injections }\end{array}$ & $\begin{array}{c}\text { High price; } \\
\text { complexity; unsuitable } \\
\text { for ferromagnetic } \\
\text { implants [35]; poor } \\
\text { imaging of targets } \\
\text { lacking } \mathrm{H}^{+} \text {protons; } \\
\text { better resolution } \\
\text { requires longer } \\
\text { imaging time; contrast } \\
\text { agents are injected }\end{array}$ \\
\hline
\end{tabular}

While histology, as the traditional gold standard for evaluating biological changes, is capable of providing the most detailed analysis and validation of the target conditions, it has severe shortcomings due to its invasive and destructive procedure which is limited to a singular time point [66]. The changes in tissue remodelling are interlinked with the structural and chemical changes of the implants, producing an increasingly complex web of multi-level interactions from molecular to functional levels that keep changing over time. As the tissue repair and remodelling progress, the priority properties of implants change accordingly - from the importance of biocompatibility at the initial stage, to tissue integration, bulk degradation rate and mechanical stability at the later stages. With the necessary requirement to acquire longitudinal data in vivo while maintaining the necessary level of detail, the modern approach is to integrate multiple imaging techniques and use a wide range of available target probes (tracers, contract agents, chromophores etc.) and specialized settings (such as T1/T2 imaging in MRI or Doppler in US).

As mentioned before, different imaging modalities show different variable properties of the imaging target-CT differentiates the attenuation coefficient of the matter, which is linked to density values, PET targets specific metabolic activities, US is for separating tissues based on their difference in acoustic impedance, USPA makes use of optical absorbance differences of molecules and MRI makes use of the magnetic properties of the $\mathrm{H}^{+}$protons and how quickly the disturbed magnetic polarization of nuclei returns to normal (therefore, image differences can be related to water content and how it is bound in tissues). The process of imaging is directly followed by image processing and analysis, the procedures that translate the visual information into quantitative and qualitative parameters. The use of mathematical comparison and evaluation through statistical methods confirms the validity of the results and allows the translation of the data between the similar cases. In implant and tissue imaging, the texture analysis is essential, and can be interpreted as classifying different images or image regions into distinct groups [87]. Most image processing software has segmentation toolkits, facilitating the manual separation of image regions, and diagnostic procedures in, for example, radiology have stably adapted the use of computer-aided diagnosis (CAD) [88]. For tissue study, it is important to distinguish 
the individual tissues, organs and regions of interest (ROI), such as the wound site or pathology. Observation of biodegradable implants requires an accurate localization of the implant and its borders, especially because of the constant changes over time. There lies the challenge of unclear border areas and artefacts, where individual judgement of the operator doing the analysis can affect the resulting data [89]. The use of machine learning, such as deep neural networks $[90,91]$, has a potential to improve the speed and accuracy of image analysis, reducing the effect of human error and differences in individual judgements. The automatic learning of useful representations and features makes it efficient and flexible, increasing the range of uses in the biomedical field to also include image acquisition and reconstruction processes [91].

It can be concluded that the multimodal and multi-parametric imaging can provide all the complimentary information and longitudinal views that are necessary in modern biomaterial research. To allow unhindered progress of research and further development, it is necessary to have a flow of information and continuous cooperation between the fields of imaging, engineering and biomedicine. Considering the wide range of involved specializations, this information needs to be easy to access and understand. Be it for translating the results "from bench to bedside" or to ensure high selectivity and sensitivity of the target data, having clear guidelines is helpful for all involved parties. This work provided an overview of the techniques that can be considered to be most suitable for imaging the processes that involve biodegradable implants. By further developing the optimal approaches for different implants and imaging targets, the resulting standardization and accumulated knowledge will promote the scientific and technological development in the field of biomaterial research.

Author Contributions: Conceptualization, L.M. and L.R.; writing—original draft preparation, L.R.; writing-review and editing, C.C., P.A., D.P., D.C. and L.M.; supervision, L.M.; funding acquisition, L.M. All authors have read and agreed to the published version of the manuscript.

Funding: This project has received funding from the European Union's Horizon 2020 Research and Innovation Programme under the Marie Skłodowska-Curie (Project: MgSafe, Grant Agreement No. 811226).

Institutional Review Board Statement: Not applicable.

Informed Consent Statement: Not applicable.

Data Availability Statement: Not applicable.

Conflicts of Interest: The authors declare no conflict of interest. 


\section{Appendix A}

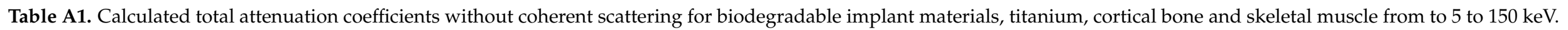

\begin{tabular}{|c|c|c|c|c|c|c|c|c|c|c|c|c|c|c|c|c|c|c|c|c|}
\hline \multicolumn{21}{|c|}{ Total Attenuation without Coherent Scattering $\mathrm{cm}^{2} / \mathrm{g}$} \\
\hline & \multicolumn{4}{|c|}{ Metals } & \multicolumn{6}{|c|}{ Ceramics } & \multicolumn{8}{|c|}{ Polymers } & \multicolumn{2}{|c|}{ Tissues } \\
\hline keV & Mg & $\mathrm{Fe}$ & $\mathrm{zn}$ & $\mathrm{Ti}$ & $\begin{array}{l}\text { Hydroxy- } \\
\text { Apatite }\end{array}$ & DCD & Brushite & TCP & TeCP & Bioglass & $\begin{array}{l}\text { Poly ( } \gamma \text {-Benzyl- } \\
\text { L-Glutamate) }\end{array}$ & $\begin{array}{c}\text { Poly- } \\
\text { Propylene } \\
\text { Fumarate }\end{array}$ & $\begin{array}{c}\begin{array}{c}\text { Poly- } \\
\text { Lactide }\end{array} \\
\text {. }\end{array}$ & $\begin{array}{c}\text { Poly- } \\
\text { Glycolide }\end{array}$ & $\begin{array}{l}\text { Poly- } \\
\text { Hydroxy- } \\
\text { Butyrate }\end{array}$ & $\begin{array}{c}\text { Poly- } \\
\text { Hydroxy- } \\
\text { Valerate }\end{array}$ & $\begin{array}{c}\text { Poly- } \\
\text { Capro- } \\
\text { Lactone }\end{array}$ & $\begin{array}{c}\text { Poly- } \\
\text { Dioxanone }\end{array}$ & $\begin{array}{c}\text { Cortical } \\
\text { Bone }\end{array}$ & $\begin{array}{l}\text { Skeletal } \\
\text { Muscle }\end{array}$ \\
\hline 5 & 157.20 & 137.40 & 208.70 & 682.00 & 312.00 & 217.60 & 217.60 & 309.30 & 329.80 & 207.80 & 24.68 & 30.31 & 30.39 & 33.85 & 28.07 & 26.39 & 25.13 & 31.08 & 182.60 & 41.98 \\
\hline $\begin{array}{c}6 \\
7.112 \\
7.112\end{array}$ & 92.87 & $\begin{array}{l}82.78 \\
55.45 \\
406.00\end{array}$ & 126.40 & 430.80 & 191.30 & 132.60 & 132.60 & 189.60 & 202.40 & 125.90 & 14.11 & 17.37 & 17.42 & 19.42 & 16.08 & 15.11 & 14.38 & 17.82 & 111.30 & $\begin{array}{l}24.26 \\
14.50\end{array}$ \\
\hline 8 & 39.91 & $\begin{array}{l}\begin{array}{l}406.00 \\
304.10\end{array} \\
3\end{array}$ & 56.75 & 201.20 & 87.12 & 59.89 & 59.89 & 86.28 & 92.34 & 56.34 & 5.83 & 7.18 & 7.21 & 8.04 & 6.66 & 6.26 & 5.96 & 7.38 & 50.34 & $\begin{array}{l}14.52 \\
10.16\end{array}$ \\
\hline 9.659 & & & $\begin{array}{r}3.345 \\
252.00\end{array}$ & & & & & & & & & & & & & & & & $\begin{array}{l}29.61 \\
29.63\end{array}$ & $\begin{array}{l}5.74 \\
5.75\end{array}$ \\
\hline 10 & 20.54 & 169.50 & 231.50 & 109.80 & 46.61 & 31.88 & 31.88 & 46.14 & 49.45 & 29.80 & 2.96 & 3.64 & 3.66 & 4.07 & 3.37 & 3.18 & 3.02 & 3.74 & 26.84 & 5.18 \\
\hline 15 & $\begin{array}{l}6.07 \\
0.52\end{array}$ & $\begin{array}{l}56.34 \\
2517\end{array}$ & $\begin{array}{l}80.24 \\
3655\end{array}$ & $\begin{array}{l}35.29 \\
11545\end{array}$ & $\begin{array}{l}14.58 \\
632\end{array}$ & $\begin{array}{l}9.92 \\
\end{array}$ & $\begin{array}{l}9.92 \\
\end{array}$ & $\begin{array}{l}14.42 \\
625\end{array}$ & $\begin{array}{l}15.49 \\
671\end{array}$ & $\begin{array}{r}9.19 \\
3.97\end{array}$ & 0.93 & $\begin{array}{l}1.12 \\
0.54\end{array}$ & $\begin{array}{l}1.13 \\
0.5\end{array}$ & 1.24 & $\begin{array}{l}1.05 \\
0.55\end{array}$ & 0.99 & 0.95 & 1.15 & 8.39 & 1.57 \\
\hline $\begin{array}{l}40 \\
50\end{array}$ & 0.43 & $\begin{array}{l}3.45 \\
1.85\end{array}$ & $\begin{array}{l}5.16 \\
2.76\end{array}$ & $\begin{array}{l}2.08 \\
111\end{array}$ & 0.91 & 0.66 & $\begin{array}{l}0.66 \\
044\end{array}$ & $\begin{array}{l}0.90 \\
0.03\end{array}$ & $\begin{array}{l}0.95 \\
0.55\end{array}$ & $\begin{array}{l}0.61 \\
038\end{array}$ & $\begin{array}{l}0.21 \\
0.12\end{array}$ & 0.21 & 0.21 & 0.22 & 0.21 & 0.21 & 0.21 & 0.21 & 0.59 & 0.24 \\
\hline $\begin{array}{l}50 \\
60 \\
60\end{array}$ & $\begin{array}{l}0.29 \\
0.22\end{array}$ & $\begin{array}{l}1.83 \\
1.11\end{array}$ & $\begin{array}{l}2.74 \\
1.65\end{array}$ & $\begin{array}{l}1.122 \\
0.70\end{array}$ & $\begin{array}{l}0.53 \\
0.36\end{array}$ & $\begin{array}{l}0.41 \\
0.30\end{array}$ & $\begin{array}{l}0.41 \\
0.30\end{array}$ & $\begin{array}{l}0.53 \\
0.36\end{array}$ & $\begin{array}{l}0.555 \\
0.38\end{array}$ & $\begin{array}{l}0.38 \\
0.28\end{array}$ & $\begin{array}{l}0.18 \\
0.18\end{array}$ & $\begin{array}{l}0.18 \\
0.18\end{array}$ & $\begin{array}{l}0.19 \\
0.18\end{array}$ & 0.19 & $\begin{array}{l}0.20 \\
0.18\end{array}$ & 0.19 & $\begin{array}{l}0.19 \\
0.18\end{array}$ & $\begin{array}{l}0.19 \\
0.18\end{array}$ & $\begin{array}{l}0.38 \\
0.88\end{array}$ & $\begin{array}{l}0.21 \\
0.19\end{array}$ \\
\hline $\begin{array}{l}60 \\
80\end{array}$ & $\begin{array}{l}0.22 \\
0.18\end{array}$ & $\begin{array}{l}1.111 \\
0.54\end{array}$ & $\begin{array}{l}1.153 \\
0.77\end{array}$ & $\begin{array}{l}0.710 \\
0.36\end{array}$ & $\begin{array}{l}0.36 \\
0.24\end{array}$ & $\begin{array}{l}0.20 \\
0.21\end{array}$ & $\begin{array}{l}0.30 \\
0.21\end{array}$ & $\begin{array}{l}0.36 \\
0.23\end{array}$ & $\begin{array}{l}. .08 \\
0.24\end{array}$ & $\begin{array}{l}.288 \\
0.20\end{array}$ & $\begin{array}{l}0.18 \\
0.17\end{array}$ & $\begin{array}{l}.18 \\
0.16\end{array}$ & $\begin{array}{l}.18 \\
0.17\end{array}$ & $\begin{array}{l}0.18 \\
0.16\end{array}$ & $\begin{array}{l}.18 \\
0.17\end{array}$ & $\begin{array}{l}.18 \\
0.17\end{array}$ & $\begin{array}{l}.18 \\
0.17\end{array}$ & $\begin{array}{l}.188 \\
0.17\end{array}$ & $\begin{array}{l}0.28 \\
0.20\end{array}$ & $\begin{array}{l}.199 \\
0.17\end{array}$ \\
\hline 100 & 0.16 & 0.33 & 0.45 & 0.24 & 0.19 & 0.18 & 0.18 & 0.18 & 0.19 & 0.17 & 0.16 & 0.15 & 0.16 & 0.15 & 0.15 & 0.16 & 0.16 & 0.16 & 0.18 & 0.16 \\
\hline 120 & 0.14 & 0.24 & 0.31 & 0.19 & 0.16 & 0.16 & 0.16 & 0.16 & 0.16 & 0.15 & 0.15 & 0.14 & 0.15 & 0.14 & 0.15 & 0.15 & 0.16 & 0.15 & 0.16 & 0.15 \\
\hline $\begin{array}{l}140 \\
150\end{array}$ & $\begin{array}{l}0.14 \\
0.13\end{array}$ & $\begin{array}{l}0.19 \\
0.18\end{array}$ & $\begin{array}{l}0.24 \\
0.21\end{array}$ & $\begin{array}{l}0.16 \\
0.15\end{array}$ & $\begin{array}{l}0.15 \\
0.14\end{array}$ & $\begin{array}{l}0.15 \\
0.14\end{array}$ & $\begin{array}{l}0.15 \\
0.14\end{array}$ & $\begin{array}{l}0.15 \\
0.14\end{array}$ & $\begin{array}{l}0.15 \\
0.14\end{array}$ & $\begin{array}{l}0.14 \\
0.14\end{array}$ & $\begin{array}{l}0.14 \\
0.14\end{array}$ & $\begin{array}{l}0.14 \\
0.14\end{array}$ & $\begin{array}{l}0.14 \\
0.14\end{array}$ & $\begin{array}{l}0.14 \\
0.14\end{array}$ & $\begin{array}{l}0.15 \\
0.15\end{array}$ & $\begin{array}{l}0.15 \\
0.14\end{array}$ & $\begin{array}{l}0.15 \\
0.15\end{array}$ & $\begin{array}{l}0.15 \\
0.14\end{array}$ & $\begin{array}{l}0.15 \\
0.15\end{array}$ & $\begin{array}{l}0.15 \\
0.14\end{array}$ \\
\hline & & & & & 0.14 & 0.14 & 0.14 & 0.14 & 0.14 & 0.14 & 0.14 & 0.14 & 0.14 & 0.14 & 0.15 & 0.14 & 0.15 & 0.14 & 0.15 & 0.14 \\
\hline
\end{tabular}




\section{References}

1. Teo, A.J.T.; Mishra, A.; Park, I.; Kim, Y.J.; Park, W.T.; Yoon, Y.J. Polymeric Biomaterials for Medical Implants and Devices. ACS Biomater. Sci. Eng. 2016, 2, 454-472. [CrossRef]

2. Saini, M. Implant Biomaterials: A Comprehensive Review. World J. Clin. Cases 2015, 3, 52. [CrossRef]

3. Rahim, M.I.; Ullah, S.; Mueller, P.P. Advances and Challenges of Biodegradable Implant Materials with a Focus on MagnesiumAlloys and Bacterial Infections. Metals 2018, 8, 532. [CrossRef]

4. Jaiswal, S.; Dubey, A.; Lahiri, D. In Vitro Biodegradation and Biocompatibility of Mg-HA-Based Composites for Orthopaedic Applications: A Review. J. Indian Inst. Sci. 2019, 99, 303-327. [CrossRef]

5. Zafar, M.S.; Ullah, R.; Qamar, Z.; Fareed, M.A.; Amin, F.; Khurshid, Z.; Sefat, F. Properties of dental biomaterials. In Avanced Dental Biomaterials; Woodhead Publishing: Duxford, UK, 2019.

6. FDA-NIH Biomarker Working Group. BEST (Biomarkers, EndpointS, and Other Tools) Resource; Food and Drug Administration (US): Silver Spring, MD, USA, 2016.

7. Chen, L.; Deng, H.; Cui, H.; Fang, J.; Zuo, Z.; Deng, J.; Li, Y.; Wang, X.; Zhao, L. Inflammatory Responses and InflammationAssociated Diseases in Organs. Oncotarget 2018, 9, 7204-7218. [CrossRef] [PubMed]

8. Shrivastava, S. ASM International. In Medical Device Materials, Proceedings of the Materials E Processes for Medical Devices Conference 2003, 8-10 September 2003, Anaheim, CA, USA; ASM International: Geauga, OH, USA, 2004.

9. Loi, F.; Córdova, L.A.; Pajarinen, J.; Lin, T.H.; Yao, Z.; Goodman, S.B. Inflammation, Fracture and Bone Repair. Bone 2016, 86, 119-130. [CrossRef]

10. Einhorn, T.A.; Gerstenfeld, L.C. Fracture Healing: Mechanisms and Interventions. Nat. Rev. Rheumatol. 2015, 11, 45-54. [CrossRef] [PubMed]

11. Radha, R.; Sreekanth, D. Insight of Magnesium Alloys and Composites for Orthopedic Implant Applications-A Review. J. Magnes. Alloys 2017, 5, 286-312. [CrossRef]

12. Wahl, D.A.; Czernuszka, J.T. Collagen-Hydroxyapatite Composites for Hard Tissue Repair. Eur. Cells Mater. 2006, 11, 43-56. [CrossRef]

13. Sun, D.; Chen, Y.; Tran, R.T.; Xu, S.; Xie, D.; Jia, C.; Wang, Y.; Guo, Y.; Zhang, Z.; Guo, J.; et al. Citric Acid-Based Hydroxyapatite Composite Scaffolds Enhance Calvarial Regeneration. Sci. Rep. 2014, 4, 1-9. [CrossRef] [PubMed]

14. Karthik, V.; Pabi, S.K.; Chowdhury, S.K.R. Development of Hydroxyapatite/Polyvinyl Alcohol Bionanocomposite for Prosthesis Implants. IOP Conf. Ser. Mater. Sci. Eng. 2018, 314, 12031. [CrossRef]

15. May, H.; Alper Kati, Y.; Gumussuyu, G.; Yunus Emre, T.; Unal, M.; Kose, O. Bioabsorbable Magnesium Screw versus Conventional Titanium Screw Fixation for Medial Malleolar Fractures. J. Orthop. Traumatol. 2020, 21, 9. [CrossRef]

16. Zheng, Y.F.; Gu, X.N.; Witte, F. Biodegradable Metals. Mater. Sci. Eng. R Rep. 2014, 77, 1-34. [CrossRef]

17. Agarwal, S.; Curtin, J.; Duffy, B.; Jaiswal, S. Biodegradable Magnesium Alloys for Orthopaedic Applications: A Review on Corrosion, Biocompatibility and Surface Modifications. Mater. Sci. Eng. C 2016, 68, 948-963. [CrossRef]

18. Fernandez de Grado, G.; Keller, L.; Idoux-Gillet, Y.; Wagner, Q.; Musset, A.M.; Benkirane-Jessel, N.; Bornert, F.; Offner, D. Bone Substitutes: A Review of Their Characteristics, Clinical Use, and Perspectives for Large Bone Defects Management. J. Tissue Eng. 2018, 9. [CrossRef]

19. Prakasam, M.; Locs, J.; Salma-Ancane, K.; Loca, D.; Largeteau, A.; Berzina-Cimdina, L. Biodegradable Materials and Metallic Implants-A Review. J. Funct. Biomater. 2017, 8, 44. [CrossRef] [PubMed]

20. Fine, S.; Hendee, C.F. X-Ray Critical-Absorption and Emission Energies in KeV. Available online: https://www.orteconline.com/-/ media/ametekortec/thirdeditionexperiments/library-x-ray_critical_abosrption_and_emission_energies.pdf?la=enLB-tTOfQ (accessed on 29 June 2021).

21. Merritt, E.A. X-Ray Absorption Edges. Available online: http://skuld.bmsc.washington.edu/scatter/AS_periodic.html (accessed on 29 June 2021).

22. Sykaras, N.; Iacopino, A.M.; Marker, V.A.; Triplett, R.G.; Woody, R.D. Implant Materials, Designs, and Surface Topographies: Their Effect on Osseointegration. A Literature Review. Int. J. Oral Maxillofac. Implant. 2020, 15, 675-690.

23. Bai, X.L.; Yang, Y.Y.; Chung, T.S.; Ng, S.; Heller, J. Effect of Polymer Compositions on the Fabrication of Poly(Ortho-Ester) Microspheres for Controlled Release of Protein. J. Appl. Polym. Sci. 2001, 80, 1630-1642. [CrossRef]

24. XL Sci-Tech, Inc. Bioactive Glass Microspheres: 4PiGraft(TM), 45S5, S53P4, 58S, 13-93. Available online: http:/ /xlscitech.com/ products/Products-Functional.html (accessed on 29 June 2021).

25. Moseke, C.; Gbureck, U. Tetracalcium Phosphate: Synthesis, Properties and Biomedical Applications. Acta Biomater. 2010, 6, 3815-3823. [CrossRef] [PubMed]

26. PubChem PubChem 2020. Available online: https:/ / pubchem.ncbi.nlm.nih.gov/ (accessed on 29 June 2021).

27. CROW A-B Polymer Class Index. Available online: http:/ / www.polymerdatabase.com/home.html (accessed on 29 June 2021).

28. Zhang, X. Science and Principles of Biodegradable and Bioresorbable Medical Polymers: Materials and Properties, 1st ed.; Zhang, X., Ed.; Woodhead Publishing: Duxford, UK, 2016; ISBN 9780081003930.

29. Fromentin, S. The Physics Factbook. In Resistivity of Carbon, Diamond. 2004. Available online: https://hypertextbook.com/facts/ (accessed on 29 June 2021). 
30. Ward, S.R.; Lieber, R.L. Density and Hydration of Fresh and Fixed Human Skeletal Muscle. J. Biomech. 2005, 38, 2317-2320. [CrossRef] [PubMed]

31. Farvid, M.S.; Ng, T.W.K.; Chan, D.C.; Barrett, P.H.R.; Watts, G.F. Association of Adiponectin and Resistin with Adipose Tissue Compartments, Insulin Resistance and Dyslipidaemia. Diabetes Obes. Metab. 2005, 7, 406-413. [CrossRef] [PubMed]

32. Martins, J.A.; Lach, A.A.; Morris, H.L.; Carr, A.J.; Mouthuy, P.-A.A. Polydioxanone Implants: A Systematic Review on Safety and Performance in Patients. J. Biomater. Appl. 2020, 34, 902-916. [CrossRef]

33. Ketcham, R.A.; Hanna, R.D. Beam Hardening Correction for X-Ray Computed Tomography of Heterogeneous Natural Materials. Comput. Geosci. 2014, 67, 49-61. [CrossRef]

34. Vedantham, S. Tissue Substitute Materials for Diagnostic X-ray Imaging. In Handbook of X-Ray Imaging: Physics and Technology; Russo, P., Ed.; CRC Press: Boca Raton, FL, USA, 2018; ISBN 9781498741521.

35. Smeets, R.; Schöllchen, M.; Gauer, T.; Aarabi, G.; Assaf, A.T.; Rendenbach, C.; Beck-Broichsitter, B.; Semmusch, J.; Sedlacik, J.; Heiland, M.; et al. Artefacts in Multimodal Imaging of Titanium, Zirconium and Binary Titanium-Zirconium Alloy Dental Implants: An in Vitro Study. Dentomaxillofacial Radiol. 2017, 46. [CrossRef] [PubMed]

36. Wellenberg, R.H.H.; Hakvoort, E.T.; Slump, C.H.; Boomsma, M.F.; Maas, M.; Streekstra, G.J. Metal Artifact Reduction Techniques in Musculoskeletal CT-Imaging. Eur. J. Radiol. 2018, 107, 60-69. [CrossRef]

37. Zhou, P.; Zhang, C.; Gao, Z.; Cai, W.; Yan, D.; Wei, Z. Evaluation of the Quality of CT Images Acquired with Smart Metal Artifact Reduction Software. Open Life Sci. 2018, 13, 155-162. [CrossRef] [PubMed]

38. Sonnow, L.; Könneker, S.; Vogt, P.M.; Wacker, F.; von Falck, C. Biodegradable Magnesium Herbert Screw-Image Quality and Artifacts with Radiography, CT and MRI. BMC Med. Imaging 2017, 17. [CrossRef] [PubMed]

39. Goo, H.W.; Goo, J.M. Dual-Energy CT: New Horizon in Medical Imaging. Korean J. Radiol. 2017, 18, 555-569. [CrossRef]

40. Wellenberg, R.H.H.; Donders, J.C.E.; Kloen, P.; Beenen, L.F.M.; Kleipool, R.P.; Maas, M.; Streekstra, G.J. Exploring Metal Artifact Reduction Using Dual-Energy CT with Pre-Metal and Post-Metal Implant Cadaver Comparison: Are Implant Specific Protocols Needed? Skelet. Radiol. 2018, 47, 839-845. [CrossRef]

41. Cyteval, C.; Bourdon, A. Imaging Orthopedic Implant Infections. Diagn. Interv. Imaging 2012, 93, 547-557. [CrossRef]

42. Roth, T.D.; Maertz, N.A.; Andrew Parr, J.; Buckwalter, K.A.; Choplin, R.H. CT of the Hip Prosthesis: Appearance of Components, Fixation, and Complications. Radiographics 2012, 32, 1089-1107. [CrossRef]

43. Kairemo, K.; Macapinlac, H.A. Sodium Fluoride PET/CT in Clinical Use; Kairemo, K., Macapinlac, H.A., Eds.; Springer International Publishing: Cham. Switzerland, 2020.

44. Hsu, W.K.; Feeley, B.T.; Krenek, L.; Stout, D.B.; Chatziioannou, A.F.; Lieberman, J.R. The Use of 18F-Fluoride and 18F-FDG PET Scans to Assess Fracture Healing in a Rat Femur Model. Eur. J. Nucl. Med. Mol. Imaging 2007, 34, 1291-1301. [CrossRef] [PubMed]

45. Brooks, P.C.; Clark, R.A.F.; Cheresh, D.A. Requirement of Vascular Integrin Avß3 for Angiogenesis. Science 1994, $264,569-571$. [CrossRef]

46. Haubner, R. Avß3-Integrin Imaging: A New Approach to Characterise Angiogenesis? Eur. J. Nucl. Med. Mol. Imaging 2006, 33, 54-63. [CrossRef] [PubMed]

47. Haubner, R.; Maschauer, S.; Prante, O. PET Radiopharmaceuticals for Imaging Integrin Expression: Tracers in Clinical Studies and Recent Developments. BioMed Res. Int. 2014, 2014. [CrossRef] [PubMed]

48. Rodenberg, E.; Azhdarinia, A.; Lazard, Z.W.; Hall, M.; Kwon, S.K.; Wilganowski, N.; Salisbury, E.A.; Merched-Sauvage, M.; Olmsted-Davis, E.A.; Sevick-Muraca, E.M.; et al. Matrix Metalloproteinase-9 Is a Diagnostic Marker of Heterotopic Ossification in a Murine Model. Tissue Eng. Part A 2011, 17, 2487-2496. [CrossRef]

49. Toczek, J.; Bordenave, T.; Gona, K.; Kim, H.Y.; Beau, F.; Georgiadis, D.; Correia, I.; Ye, Y.; Razavian, M.; Jung, J.J.; et al. Novel Matrix Metalloproteinase 12 Selective Radiotracers for Vascular Molecular Imaging. J. Med. Chem. 2019, 62, 9743-9752. [CrossRef]

50. Son, H.J.; Jeong, Y.J.; Yoon, H.J.; Wang, L.; Kim, H.J.; Park, J.H.; Kang, D.Y. Visual Pattern and Serial Quantitation of 18F-Sodium Fluoride PET/CT in Asymptomatic Patients After Hip and Knee Arthroplasty. Nucl. Med. Mol. Imaging 2016, 50, 308-321. [CrossRef]

51. Martin, O.; Boos, J.; Aissa, J.; Vay, C.; Heusch, P.; Gaspers, S.; Antke, C.; Sedlmair, M.; Antoch, G.; Schaarschmidt, B.M. Impact of Different Iterative Metal Artifact Reduction (IMAR) Algorithms on PET/CT Attenuation Correction after Port Implementation. Eur. J. Radiol. 2020, 129, 109065. [CrossRef] [PubMed]

52. Reinert, C.P.; la Fougère, C.; Nikolaou, K.; Pfannenberg, C.; Gatidis, S. Value of CT Iterative Metal Artifact Reduction in PET/CT_Clinical Evaluation in 100 Patients. Br. J. Radiol. 2019, 92, 20180756. [CrossRef] [PubMed]

53. Guy, C.; Ffytche, D. An Introduction to the Principles of Medical Imaging; Imperial College Press: London, UK, 2000.

54. ter Haar, G. Ultrasonic Imaging: Safety Considerations. Interface Focus 2011, 1, 686-697. [CrossRef] [PubMed]

55. Hoppenfeld, S. Treatment and Rehabilitation of Fractures; Lippincott Williams \& Wilkins: Philadelphia, PA, USA, 2000; ISBN 9780781721974.

56. Bhaskar, V.; Chan, H.L.; MacEachern, M.; Kripfgans, O.D. Updates on Ultrasound Research in Implant Dentistry: A Systematic Review of Potential Clinical Indications. Dentomaxillofacial Radiol. 2018, 47, 20180076. [CrossRef]

57. Tang, S.; Shajudeen, P.; Tasciotti, E.; Righetti, R. Identification of Ultrasound Imaging Markers to Quantify Long Bone Regeneration in a Segmental Tibial Defect Sheep Model in Vivo. Sci. Rep. 2020, 10. [CrossRef]

58. Steinberg, I.; Huland, D.M.; Vermesh, O.; Frostig, H.E.; Tummers, W.S.; Gambhir, S.S. Photoacoustic Clinical Imaging. Photoacoustics 2019, 14, 77-98. [CrossRef] 
59. Lee, D.; Park, S.; Noh, W.-C.; Im, J.-S.; Kim, C. Photoacoustic Imaging of Dental Implants in a Porcine Jawbone Ex Vivo. Opt. Lett. 2017, 42, 1760. [CrossRef]

60. Sharma, A.; Srishti; Periyasamy, V.; Pramanik, M. Photoacoustic Imaging Depth Comparison at 532-, 800-, and 1064-Nm Wavelengths: Monte Carlo Simulation and Experimental Validation. J. Biomed. Opt. 2019, 24, 1. [CrossRef]

61. Burgholzer, P.; Bauer-Marschallinger, J.; Haltmeier, M. Breaking the Resolution Limit in Photoacoustic Imaging Using NonNegativity and Sparsity. Photoacoustics 2020, 19, 100191. [CrossRef]

62. Wang, L.V.; Hu, S. Photoacoustic Tomography: In Vivo Imaging from Organelles to Organs. Science 2012, 335, 1458-1462. [CrossRef] [PubMed]

63. Li, M.; Tang, Y.; Yao, J. Photoacoustic Tomography of Blood Oxygenation: A Mini Review. Photoacoustics 2018, 10, 65-73. [CrossRef] [PubMed]

64. Berger, A. Magnetic Resonance Imaging. BMJ 2002, 324, 35. [CrossRef] [PubMed]

65. Anwander, H.; Cron, G.O.; Rakhra, K.; Beaule, P.E. Perfusion MRI in Hips with Metal-on-Metal and Metal-on-Polyethylene Total Hip Arthroplasty: A Pilot Study. Bone Jt. Res. 2016, 5, 73-79. [CrossRef]

66. Berry, D.B.; Englund, E.K.; Chen, S.; Frank, L.R.; Ward, S.R. Medical Imaging of Tissue Engineering and Regenerative Medicine Constructs. Biomater. Sci. 2021, 9, 301-314. [CrossRef] [PubMed]

67. Drogset, J.O.; Grøntvedt, T.; Myhr, G. Magnetic Resonance Imaging Analysis of Bioabsorbable Interference Screws Used for Fixation of Bone-Patellar Tendon-Bone Autografts in Endoscopic Reconstruction of the Anterior Cruciate Ligament. Am. J. Sports Med. 2006, 34, 1164-1169. [CrossRef]

68. Frosch, K.H.; Sawallich, T.; Schütze, G.; Losch, A.; Walde, T.; Balcarek, P.; Konietschke, F.; Stürmer, K.M. Magnetic Resonance Imaging Analysis of the Bioabsorbable Milagro ${ }^{\mathrm{TM}}$ Interference Screw for Graft Fixation in Anterior Cruciate Ligament Reconstruction. Strateg. Trauma Limb Reconstr. 2009, 4, 73-79. [CrossRef] [PubMed]

69. Warden, W.H.; Friedman, R.; Teresi, L.M.; Jackson, D.W. Magnetic Resonance Imaging of Bioabsorbable Polylactic Acid Interference Screws during the First 2 Years after Anterior Cruciate Ligament Reconstruction. Arthrosc. J. Arthrosc. Relat. Surg. 1999, 15, 474-480. [CrossRef] [PubMed]

70. Kim, Y.H.; Choi, M.; Kim, J.W. Are Titanium Implants Actually Safe for Magnetic Resonance Imaging Examinations? Arch. Plast. Surg. 2019, 46, 96-97. [CrossRef]

71. Bian, D.; Qin, L.; Lin, W.; Shen, D.; Qi, H.; Shi, X.; Zhang, G.; Liu, H.; Yang, H.; Wang, J.; et al. Magnetic Resonance (MR) Safety and Compatibility of a Novel Iron Bioresorbable Scaffold. Bioact. Mater. 2020, 5, 260-274. [CrossRef]

72. Fragogeorgi, E.A.; Rouchota, M.; Georgiou, M.; Velez, M.; Bouziotis, P.; Loudos, G. In Vivo Imaging Techniques for Bone Tissue Engineering. J. Tissue Eng. 2019, 10. [CrossRef]

73. Regelink, J.C.; Raijmakers, P.G.; Bravenboer, N.; Milek, R.; Hoetjes, N.J.; de Kreuk, A.M.; van Duin, M.; Wondergem, M.J.; Lips, P.; Sonneveld, P.; et al. 18F-Fluoride-PET for Dynamic in vivo Monitoring of Bone Formation in Multiple Myeloma. EJNMMI Res. 2016, 6, 46. [CrossRef]

74. Moran, C.M.; Thomson, A.J.W. Preclinical Ultrasound Imaging-A Review of Techniques and Imaging Applications. Front. Phys. 2020, 8, 124. [CrossRef]

75. Krishnamoorthy, S.; Blankemeyer, E.; Mollet, P.; Surti, S.; van Holen, R.; Karp, J.S. Performance Evaluation of the MOLECUBES $\beta$-CUBE-A High Spatial Resolution and High Sensitivity Small Animal PET Scanner Utilizing Monolithic LYSO Scintillation Detectors. Phys. Med. Biol. 2018, 63, 155013. [CrossRef] [PubMed]

76. Lin, F.; Shelton, S.E.; Espíndola, D.; Rojas, J.D.; Pinton, G.; Dayton, P.A. 3-D Ultrasound Localization Microscopy for Identifying Microvascular Morphology Features of Tumor Angiogenesis at a Resolution beyond the Diffraction Limit of Conventional Ultrasound. Theranostics 2017, 7, 196-204. [CrossRef] [PubMed]

77. Linxweiler, J.; Körbel, C.; Müller, A.; Jüngel, E.; Blaheta, R.; Heinzelmann, J.; Stöckle, M.; Junker, K.; Menger, M.D.; Saar, M. Experimental Imaging in Orthotopic Renal Cell Carcinoma Xenograft Models: Comparative Evaluation of High-Resolution 3D Ultrasonography, in-Vivo Micro-CT and 9.4T MRI. Sci. Rep. 2017, 7, 14249. [CrossRef]

78. Vaidyanathan, S.; Patel, C.N.; Scarsbrook, A.F.; Chowdhury, F.U. FDG PET/CT in Infection and Inflammation-Current and Emerging Clinical Applications. Clin. Radiol. 2015, 70, 787-800. [CrossRef] [PubMed]

79. Shrestha, B.; Deluna, F.; Anastasio, M.A.; Yong Ye, J.; Brey, E.M. Photoacoustic Imaging in Tissue Engineering and Regenerative Medicine. Tissue Eng. Part B Rev. 2020, 26, 79-102. [CrossRef]

80. Taha, M.A.; Manske, S.L.; Kristensen, E.; Taiani, J.T.; Krawetz, R.; Wu, Y.; Ponjevic, D.; Matyas, J.R.; Boyd, S.K.; Rancourt, D.E.; et al. Assessment of the Efficacy of MRI for Detection of Changes in Bone Morphology in a Mouse Model of Bone Injury. J. Magn. Reson. Imaging 2013, 38, 231-237. [CrossRef]

81. Zlotorowicz, M.; Czubak, J.; Kozinski, P.; Boguslawska-Walecka, R. Imaging the Vascularisation of the Femoral Head by CT Angiography. J. Bone Jt. Surgery. Br. Vol. 2012, 94-B, 1176-1179. [CrossRef]

82. Menichetti, L.; Kusmic, C.; Panetta, D.; Arosio, D.; Petroni, D.; Matteucci, M.; Salvadori, P.A.; Casagrande, C.; L'Abbate, A.; Manzoni, L. MicroPET/CT Imaging of Avß3 Integrin via a Novel 68Ga-NOTA-RGD Peptidomimetic Conjugate in Rat Myocardial Infarction. Eur. J. Nucl. Med. Mol. Imaging 2013, 40, 1265-1274. [CrossRef]

83. Siitonen, R.; Peuhu, E.; Autio, A.; Liljenbäck, H.; Mattila, E.; Metsälä, O.; Käkelä, M.; Saanijoki, T.; Dijkgraaf, I.; Jalkanen, S.; et al. 68Ga-DOTA-E[C(RGDFK)]2 PET Imaging of Sharpin-Regulated Integrin Activity in Mice. J. Nucl. Med. 2019, 60, 1380-1387. [CrossRef] 
84. Wang, J.; Qin, B.; Chen, X.; Wagner, W.R.; Villanueva, F.S. Ultrasound Molecular Imaging of Angiogenesis Using Vascular Endothelial Growth Factor-Conjugated Microbubbles. Mol. Pharm. 2017, 14, 781-790. [CrossRef]

85. Cosgrove, D. Angiogenesis Imaging - Ultrasound. Br. J. Radiol. 2003, 76, S43-S49. [CrossRef] [PubMed]

86. Woloszyk, A.; Wolint, P.; Becker, A.S.; Boss, A.; Fath, W.; Tian, Y.; Hoerstrup, S.P.; Buschmann, J.; Emmert, M.Y. Novel Multimodal MRI and MicroCT Imaging Approach to Quantify Angiogenesis and 3D Vascular Architecture of Biomaterials. Sci. Rep. 2019, 9. [CrossRef] [PubMed]

87. Pietikäinen, M.K. Texture Analysis in Machine Vision; Series in Machine Perception and Artificial Intelligence; WORLD SCIENTIFIC: Singapore, 2000; Volume 40, ISBN 978-981-02-4373-9.

88. Ahmadvand, A.; Reza Daliri, M. A Review on Texture Analysis Methods in Biomedical Image Processing. OMICS J. Radiol. 2016, 5. [CrossRef]

89. Ayyad, S.M.; Shehata, M.; Shalaby, A.; Abou El-Ghar, M.; Ghazal, M.; El-Melegy, M.; Abdel-Hamid, N.B.; Labib, L.M.; Ali, H.A.; El-Baz, A. Role of Ai and Histopathological Images in Detecting Prostate Cancer: A Survey. Sensors 2021, 21, 2586. [CrossRef]

90. Andrearczyk, V.; Whelan, P.F. Using Filter Banks in Convolutional Neural Networks for Texture Classification. Pattern Recognit. Lett. 2016, 84, 63-69. [CrossRef]

91. Lundervold, A.S.; Lundervold, A. An Overview of Deep Learning in Medical Imaging Focusing on MRI. Z. Med. Phys. 2019, 29, 102-127. [CrossRef] 